\title{
Biogeography in deep time - What do phylogenetics, geology, and paleoclimate tell us about early platyrrhine evolution?
}

\author{
Richard F. Kay \\ Department of Evolutionary Anthropology E Division of Earth and Ocean Sciences, Duke University, Box 90383, Durham, NC 27708, United States
}

\section{A R T I C L E I N F O}

\section{Article history:}

Available online $\mathrm{xxxx}$

\section{Keywords:}

Platyrrhini

Oligocene

Miocene

South America

Paraná Portal

Anthropoidea

\begin{abstract}
A B S T R A C T
Molecular data have converged on a consensus about the genus-level phylogeny of extant platyrrhine monkeys, but for most extinct taxa and certainly for those older than the Pleistocene we must rely upon morphological evidence from fossils. This raises the question as to how well anatomical data mirror molecular phylogenies and how best to deal with discrepancies between the molecular and morphological data as we seek to extend our phylogenies to the placement of fossil taxa.

Here I present parsimony-based phylogenetic analyses of extant and fossil platyrrhines based on an anatomical dataset of 399 dental characters and osteological features of the cranium and postcranium. I sample 16 extant taxa (one from each platyrrhine genus) and 20 extinct taxa of platyrrhines. The tree structure is constrained with a "molecular scaffold" of extant species as implemented in maximum parsimony using PAUP with the molecular-based 'backbone' approach. The data set encompasses most of the known extinct species of platyrrhines, ranging in age from latest Oligocene ( $\sim 26 \mathrm{Ma})$ to the Recent. The tree is rooted with extant catarrhines, and Late Eocene and Early Oligocene African anthropoids.

Among the more interesting patterns to emerge are: (1) known early platyrrhines from the Late Oligocene through Early Miocene (26-16.5 Ma) represent only stem platyrrhine taxa; (2) representatives of the three living platyrrhine families first occur between $15.7 \mathrm{Ma}$ and $13.5 \mathrm{Ma}$; and (3) recently extinct primates from the Greater Antilles (Cuba, Jamaica, Hispaniola) are sister to the clade of extant platyrrhines and may have diverged in the Early Miocene. It is probable that the crown platyrrhine clade did not originate before about 20-24 Ma, a conclusion consistent with the phylogenetic analysis of fossil taxa presented here and with recent molecular clock estimates.

The following biogeographic scenario is consistent with the phylogenetic findings and climatic and geologic evidence: Tropical South America has been a center for platyrrhine diversification since platyrrhines arrived on the continent in the middle Cenozoic. Platyrrhines dispersed from tropical South America to Patagonia at $\sim 25-24$ Ma via a "Paraná Portal" through eastern South America across a retreating Paranense Sea. Phylogenetic bracketing suggests Antillean primates arrived via a sweepstakes route or island chain from northern South America in the Early Miocene, not via a proposed land bridge or island chain (GAARlandia) in the Early Oligocene ( $34 \mathrm{Ma}$ ). Patagonian and Antillean platyrrhines went extinct without leaving living descendants, the former at the end of the Early Miocene and the latter within the past six thousand years. Molecular evidence suggests crown platyrrhines arrived in Central America by crossing an intermittent connection through the Isthmus of Panama at or after 3.5 Ma. Any more ancient Central American primates, should they be discovered, are unlikely to have given rise to the extant Central American taxa in situ.
\end{abstract}

(c) 2013 Elsevier Inc. All rights reserved.

\section{Introduction}

Living Platyrrhini (New World monkeys, platyrrhines) are conspicuous elements of modern Neotropical faunas, with at least 16 commonly recognized genera and up to 16 sympatric species. The past few decades have witnessed a greatly expanded representation of fossil taxa spanning the past 26 million years of earth history. In this context it is notable that the last phylogenetic analysis

E-mail address: Richard.kay@duke.edu to include most of the living and extinct platyrrhines was in 1999 (Horovitz, 1999). New fossil material and an improved phylogenetic framework for the living taxa provide an opportunity for a more nuanced overview of platyrrhine origins and cladogenesis. In this paper I discuss the evidence this fossil record provides about the phylogenetic and geographic history of the clade, as well as outlining evidence bearing on some of the more contentious issues of platyrrhine phylogeny.

At the generic level, molecular evidence analyzed through phylogenetic methods has converged on a consensus about platyrrhine 
phylogeny (Opazo et al., 2006; Osterholz et al., 2009; Wildman et al., 2009; Perelman et al., 2011; Springer et al., 2012). There remains considerable disagreement about (1) the timing of the branches of this phylogeny, (2) whether some morphological systems should be accorded heavier weight than others in a phylogenetic analysis, and (3) whether the molecular evidence of extant taxa should be taken into account when interpreting the phylogenetic position of extinct taxa.

In the first instance, in spite of rapidly accumulating data and methodological progress, branch times remain poorly constrained and subject to substantial variance (Opazo et al., 2006; Schrago, 2007; Hodgson et al., 2009).

As to the second point, it has been argued that some classes of morphological data yield closer correspondence to molecular phylogenies (Collard and Wood, 2000). But recent work points to the disutility of claims that one or another sort of morphological data has a more reliable phyletic signal than another (Strait and Grine, 2004; Williams, 2007).

Regarding the third point, I have argued, as have many others, that morphologists and paleontologists must take into account molecular data when interpreting the fossil evidence of anthropoid phylogeny (Horovitz, 1999; Horovitz and MacPhee, 1999; Marivaux, 2006; Kay et al., 2008a; Seiffert et al., 2009; Kay and Fleagle, 2010). A complete phylogenetic analysis must take into account the now-vast amount of information embodied in molecular studies. Moreover, as noted, for example by Koepfli et al. (2007), disagreement with prior fossil and morphology-based assessments often is accounted for by morphological similarities reflecting adaptive convergence rather than ancestry. Further, incongruence between the molecular and morphological datasets may be due to non-independence among developmentally and genetically correlated atomized morphological characters (e.g., Rosenberger, 2011).

As important as it is for paleontologists to reconcile explicitly morphological and molecular data sets, likewise it is critical that molecular divergence times be accurately calibrated from paleontological evidence. Incorrect phylogenetic placement of fossils can introduce large calibration errors and inaccurate divergencedate estimates (Parham et al., 2012). Poorly known fossils often provide insufficient anatomical evidence to discriminate whether shared characters are products of convergence or common descent. Given the very high rates of homoplasy reported for morphological characters (in the range of $30-40 \%$ for the number of taxa used in platyrrhine phylogenetic analyses), it becomes vital to perform a phylogenetic analysis, rather that relying on a few arbitrarily selected characters. Parham et al. (2012) offer a useful checklist that must be fulfilled before a calibration can be justified, of which their third recommendation is absolutely critical in the present work: that an explicit, up-to-date, phylogenetic analysis be offered that includes the reference specimens underlying the fossil calibrations. In turn, if the divergence times are inaccurate or the fossils are wrongly placed on the trees; biogeographic scenarios will be subject to error.

A phylogenetic analysis that includes living and extinct platyrrhines must by its nature include morphological characters because those are the only source of information about extinct animals. But also as recommended by Parham et al. (2012) the analysis must take into account the rich and ever-expanding molecular evidence regarding extant taxa (Kay and Williams, 1994; Kay et al., 2008a; Kay and Fleagle, 2010).

An early example of such a combined analysis for platyrrhines comes from the pioneering work of Horovitz (1999), who used approximately 100 morphological, mostly dental, characters. Horovitz combined this morphological data with DNA sequence data from a fragment of the $16 \mathrm{~S}$ and the entire $12 \mathrm{~S}$ mitochondrial genes, consisting of $\sim 1000$ informative sites. Kay et al. (2008a) took a different approach using a 'molecular scaffold' (Springer et al., 2001). Such an approach seems appropriate for platyrrhines because the number of informative DNA loci far exceeds the number of morphological characters (Wildman et al., 2009). The addition of SINE and LINE data helps to resolve the remaining uncertainties about phylogenetic placement of extant taxa (Osterholz et al., 2009). Taking the molecular evidence into account by using a 'molecular scaffold' Kay et al. (2008a) evaluated 268 cranial and dental characters in five Late Eocene-Early Oligocene African anthropoids, three extant catarrhines, 16 extant platyrrhines and five extinct Patagonian Miocene platyrrhines. The new analysis presented here retains the molecular scaffold approach but greatly expands the morphological character-taxon matrix, adding postcranial and deciduous dental characters, and most of the recognized taxa of Late Oligocene to Recent platyrrhine fossil genera, excepting only the fossil atelids from the caves of Brazil (which I have not examined) and a few poorly preserved or dubious taxa, which are discussed but not analyzed.

In keeping with the subject of this issue, I consider several biogeographic questions: (1) When and from where did platyrrhines reach South America and do they have an identifiable sister group outside the continent? (2) What is the fossil evidence for the antiquity of the extant clades of platyrrhines? (3) Where do the Patagonian, Antillean, and Central American primates fit in the platyrrhine clade? Questions 2 and 3 have an interesting symmetry. Some recognize Late Oligocene-Early Miocene 'Southern' (i.e., Bolivian, Chilean and Patagonian) platyrrhines as representing extant platyrrhine families (Rosenberger, 2002, 2011; Tejedor, 2013), whilst others see them as a geographically isolated radiation of stem platyrrhines collateral to the evolution of modern forms (Kay et al., 2008a; Kay and Fleagle, 2010). Likewise, one school of thought is that the Antillean primates belong to several clades of extant platyrrhines (Rosenberger, 2002; Rosenberger et al., 2011) whilst others see them as a single geographically isolated radiation of platyrrhines (MacPhee and Horovitz, 2004).

In each case, the fundamental question is whether either or both the Southern or Antillean species are crown platyrrhines or, alternatively, stem taxa that are ecological 'vicars' occupying similar niches to those of some extant taxa (Elton, 1927; Eldredge, 1985; Fleagle and Kay, 1997; Kay and Fleagle, 2010).

A fully formed scenario of platyrrhine evolution begins with the phylogenetic analysis of living and extinct taxa but must also take into account important events in climatic and geologic history (Iturralde-Vinent and MacPhee, 1999). In this spirit, I propose a scenario of platyrrhine cladogenesis in the context of global and local climate change and the timing and nature of geographic barriers to dispersal.

\section{Materials and methods}

I used maximum parsimony in the analysis of morphological data, as implemented in PAUP (Swofford, 2002) (specific version 4.0a129). A description of morphological characters is presented in Supplemental Table 1. Of 399 total characters used in the analyses, 177 characters are 'ordered', and 222 characters are 'unordered'. In the analyses, a multistate character is designated as "ordered" only if it is considered that changes from one state to another require passing through intermediate states also

\footnotetext{
The Elton (1927, p. 64) defined niche and coined the term ecological vicar: "the 'niche' of an animal means its place in the biotic environment, its relations to food and enemies. The ecologist should cultivate the habit of looking at animals from this point of view as well as from the ordinary standpoints of appearance, names, affinities, and past history. When an ecologist says 'there goes a badger' he should include in his thoughts some definite idea of the animal's place in the community to which it belongs, just as if he had said 'there goes the vicar.'
} 
represented in the data set (e.g., to go from "absent" to "large" one must pass through the state "small") (Slowinski, 1993). Ordered multistate characters are set to have the same weight regardless of the number of character states. The total breadth of each morphocline is set to a base weight of 100 . For a two-state character it takes one step to cross the morphocline ( 0 to 1 or 1 to 0 ) and each step is assigned a weight of 100 . For ordered multistate characters it takes two or more steps to cross the morphocline (e.g., 0 to 1 , and 1 to 2 , or the reverse), so each step is assigned a proportionate value of (e.g., 50). This eliminates the situation in which ordered multistate characters, because they use more steps, would otherwise have more weight and thus differentially influence tree topologies. The weights of the characters are enumerated in Supplemental Tables 1 and 2 .

Specimens of extinct taxa examined are listed in Table 1, which also provides notes concerning taxonomic evaluations of the taxa, especially those placed in synonymy. The character-taxon matrix for this study is presented in Supplemental Table 2. In crafting the matrix, many judgments have been made to synonymize named taxa and allocate particular specimens to a taxon. Some of these choices are fairly obvious, as in the case of the synonymy of Neosaimiri fieldsi with Laventiana annectens or Branisella boliviana with Szalatavus attricuspis. In each case the type specimens preserve the same anatomical part, a mandible in the former case and a maxilla in the latter case and additional material from the same localities and stratigraphic levels blurs the supposed anatomical distinctiveness of the two (Takai, 1994; Takai et al., 2000). In other cases, the synonymy is not subject to direct test. For example, the type specimen of Homunculus patagonicus is a mandible, whereas that of Killikaike blakei is a palate and face (Perry et al., in press). The two are very similar in size, and come from the same formation but no specimen exists that preserves the maxilla and mandible of the same individual. Nor, in general in fossil platyrrhines, are there associations of cranial or mandibular specimens with the postcranial material that has been allocated to it (Cebupithecia sarmientoi is a rare exception).

Several species of fossil platyrrhines are left out of the comprehensive analysis for different reasons. The fossil atelids (Protopithecus, Caipora) from Pleistocene-Holocene caves in Brazil were not scored in the matrix because I have not studied them. All authorities agree that they represent crown atelids, an opinion with which I agree. The specimen IGM KU-8403 is a single tooth and part of the hypodygm of Middle Miocene Micodon. I consider the tooth to belong to a crown callitrichine but it lacks sufficient distinctive morphological features to be included in the analysis (see also Kay and Meldrum, 1997). I consider Late Miocene Solimoea to be sister to Lagothrix (Kay and Cozzuol, 2006) but the single specimen was not included in the analysis because of its fragmentary nature. Likewise Miocallicebus is in most respects indistinguishable from Callicebus (Takai et al., 2001) but was excluded from the analysis as it is known only from a single maxilla with heavily worn and damaged teeth. On the other hand, Acrecebus, although it is known only from a single maxillary molar was included because its molar structure is highly distinctive and shared with Cebus alone among platyrrhines (Kay and Frailey, 1993; Kay and Cozzuol, 2006).

Finally, I use the genus as the taxonomic unit of study because in most cases species identification is speculative, there being insufficient numbers of specimens allowing an assessment of individual variation. A list of specimens upon which the craniodental characters was based is provided by Kay et al. (2008a). A further list of sources for the postcranial and deciduous dental characters is given in Supplemental Table 2.

In all analyses using PAUP, the distinction between polymorphic and uncertain character states was enforced. The tree-bisec- tion-reconnection (TBR) branch-swapping algorithms of PAUP were selected. For each set of comparisons, starting trees were obtained via stepwise addition with a random-addition sequence with one tree held at each step. Each analysis was replicated 1000 times.

To determine if the data partitions had significantly different phylogenetic signals, the data from 16 extant taxa was partitioned into three components: dental and masticatory (280 informative characters ${ }^{2}$ ), cranial (non-masticatory) (41 informative characters), and postcranial (67 informative characters). Partition homogeneity (incongruence length difference) tests (Farris et al., 1995) were conducted in PAUP with 1000 test replicates. Following Cunningham (1997), a probability value of 0.01 was taken as a significance criterion for these tests.

Two analyses using the total dataset were undertaken. First, I analyzed the morphological data for the extant taxa alone without constraint to determine if the morphological data yield results similar to those produced by molecular data. Second, for the joint analyses of extant and extinct taxa, following the recommendation of Springer et al. (2001), I set a "molecular scaffold" upon which to superimpose the morphological characters using the "Constraints Backbone" option of PAUP. Under the "backbone" constraint, extinct taxa are unconstrained and can move about on the molecular phylogenetic scaffold of extant taxa. Springer et al. argued that clades established by maximum parsimony analysis of molecular data should be assumed to depict a clade accurately if they receive $\geqslant 90 \%$ bootstrap support. Molecular sequence data (along with Alu data in some cases) establishes the phylogenetic relationships among extant platyrrhine genera to a high degree of certainty (Fig. 1).

\section{Results and discussion}

Before proceeding to an analysis of extinct taxa for which only morphological data is available, I explore the morphological data for 16 extant platyrrhine taxa alone with two questions in mind: (1) Is there congruence between various partitions of the morphological data, e.g., do characters of the dentition and masticatory apparatus yield a significantly different phylogenetic pattern that those of the postcranial anatomy? (2) Does the morphological dataset yield the same phylogenetic pattern as that of the molecular?

\subsection{Partition homogeneity}

The partition homogeneity/incongruence-length difference test is a means of determining if different partitions of the data (masticatory, [characters of the jaws and teeth], non-masticatory cranial, and postcranial) have significantly different signals. The overall test for homogeneity among the three sets analyzed together yields a $P$ value of $1-(26 / 1000)=0.004$ (significant), suggesting that some partitions yield significantly different trees. Further analysis reveals no significant difference between masticatory and non-masticatory cranial characters $(P$ value $=1-(996)$ $1000)=0.97$ ), so all cranial and dental characters were joined into a single partition. Comparison between 321 phylogenetically informative craniodental characters with 67 informative postcranial characters yields a $P$ value $=1-(993 / 1000)=0.007$. The different craniodental and postcranial results are presented in Fig. 2. In a visual comparison, neither the cladograms that optimize the craniodental (Fig. 2A) or postcranial (Fig. 2B) data partitions show

\footnotetext{
${ }^{2}$ With removal of outgroups and extinct taxa, the number of informative characters is reduced from the original dataset set of 399 characters to a smaller set of 388 characters.
} 
(taxa used in the phylogenetic analyses with notes on their age and provenience. Except as noted, dates of occurrence are based upon paleomagnetic and radiometric studies summarized by Flynn et al. (1997), Madden et al. (1997). Ré et al. (2010), Dunn et al. (2013), and Perkins et al. (2012). Colombian geomagnetics recalibrated from Gradstein et al. (2004). Data for living taxa is based on vouchered skeletal specimens listed in Kay et al. (2008a).

Material sources and selected

Branisella boliviana Hofstetter, 1969

Salla, Bolivia

Late Oligocene, $26 \mathrm{Ma}$

Stem platyrrhine

Chilecebus carrascoensis Flynn et al., 1995

Tremacebus harringtoni (Hershkovitz, 1974)

Dolichocebus gaimanensis Kraglievich, 1951

Mazzonicebus almendrae Kay, 2010

Carlocebus spp. Fleagle, 1990

Soriacebus spp. Fleagle et al., 1987

Homunculus spp. Ameghino, 1891

Proteropithecia neuquenensis Kay et al., 1999

Nuciruptor rubricae Meldrum and Kay, 1997

Mohanamico hershkovitzi Luchterhand et al.1986

Abanico Formation, Early Miocene, $20-21 \mathrm{Ma}$ long the Río Las Leñas,

Chile

Sacanana, Chubut

Province, Argentina

Gaiman, Chubut

Province, Argentina

Gran Barranca, Chubut

Pinturas Formation

Santa Cruz Province,

Argentina

Pinturas Formation,

Santa Cruz Province,

Argentin

Santa Cruz Formation, Late Early Miocene, 17.9-16.5 Ma

Santa Cruz Province,

Argentina

Cañadon del Tordillo, Middle Miocene, $<15.7 \mathrm{Ma}$ Neuquen Province,

Argentina

Honda Group, La Venta, Middle Miocene, 12.4-12.8 Ma

Huila, Colombia

Honda Group, La Venta, Middle Miocene, 12.2 Ma

“Aotus" dindensis Setoguchi and Rosenberger, 1987 Honda Group, La Venta, Middle Miocene, 13.0-13.2 Ma Huila, Colombia

Cebupithecia sarmientoi Stirton, 1951

Stirtonia spp. (Hershkovitz, 1970)

Neosaimiri fieldsi Stirton, 195

Patasola magdalenae Kay and Meldrum, 1997

Lagonimico conclucatus Kay, 1994

Honda Group, La Venta, Middle Miocene, 13.0-13.6 Ma Huila, Colombia

Honda Group, La Venta, Middle Miocene, 12.8-13.6 Ma Huila, Colombia

Honda Group, La Venta, Middle Miocene, 12.0-13.2 Ma Huila, Colombia

Honda Group, La Venta, Middle Miocene, 13.4-13.6 Ma Huila, Colombia

Honda Group, La Venta, Middle Miocene, 13.4-13.6 Ma Huila, Colombia, Middle

Miocene, Colombia

Micodon kiotensis Setoguchi and Rosenberger, 1985 Honda Group, La Venta, Middle Miocene, 13.0-13.2 Ma Huila, Colombia

Miocallicebus villaviejai Takai et al., 2001

Acrecebus fraileyi Kay and Cozzuol, 2006

Stem platyrrhin
Honda Group, La Venta, Middle Miocene, 13.2-13.9 Ma Huila, Colombia

Bandeira, upper Acre 6-9 Ma, based on Huayquerian faunal age Cebus River, Acre State, Brazil (Negri et al., 2010)

Pitheciidae, sister to references

Szalatavus Rosenberger et al. 1991a FLMNH, MNHN-Bol-V (Takai an

(Rosenberger et al., 1991b) was placed Anaya, 1996; Takai et al., 2000;

in synonymy with Branisella Kay et al., 2002) SGOPV (Flynn et al., 1995)

Stem platyrrhine

Stem platyrrhine

Stem platyrrhine

Stem platyrrhine

Stem platyrrhine

Stem platyrrhine

Pitheciidae, stem

Pitheciinae

Pitheciidae, stem Pitheciinae

Cebidae, stem

Callitrichinae

Pitheciidae, stem

Pitheciinae

Atelidae, sister to

Alouatta

Cebidae, sister to

Saimiri

Cebidae, stem

Callitrichinae

Cebidae, stem

Callitrichinae

IGM-KU 8403 is a stem Type specimen is a specimen of Neosaimiri: a referred specimen (ICM KU 8403) is a distinct and unname KU 8403

Age based on faunal correlation to Colhuehuapian Mammal age

Age based on faunal correlation to

Colhuehuapian Mammal age

FML (Hershkovitz, 1974, Kay et al., 2004a)

MACN, MPEF (Kay et al., 2008a;

Kay and Fleagle, 2010)

MLP, MPEF (Kay, 2010)

(ne based on faunal correlation to early MACN (Fleagle, 1990) Santacrucian ('Pinturan') Mammal age

Age based on faunal correlation to early MACN (Fleagle et al., 1987) Santacrucian ('Pinturan') Mammal age

Killikaike Tejedor et al., 2006 is probably MACN, CORD-PZ, MPM-PV a second species of Homunculus (Tejedor et al., 2006; Tejedor an Rosenberger, 2008; Kay et al. 2012a)

MLP (Kay et al., 1998a)

IGM (Meldrum and Kay, 1997)

IGM (Luchterhand et al., 1986)

This taxon is probably conspecific with IGM (Setoguchi and Rosenberger Monhanamico (Kay, 1990)

1987; Kay, 1990; Rosenberger

t al, 1990a)

UCMP, IGM (Kay, 1990)

Also recorded at Patos, upper Acre River, UCMP, IGM, LACM (Kay et al., $\begin{array}{ll}\text { Acre State, Brazil at 6-9 Ma 1987; Kay and Cozzuol, 2006) } & \end{array}$ Laventiana Rosenberger et al., 1991b UCMP, IGM (Rosenberger et al. was placed in synonymy with

Neosaimir

Based on one juvenile specimen, not IGM (Kay and Meldrum, 1997) included in analysis

IGM (Kay, 1994)

IGM-KU (Setoguchi and

Rosenberger, 1985; Kay and Meldrum, 1997)

IGG-KU (Takai et al., 2001)

LACM (Kay and Cozzuol, 2006) 


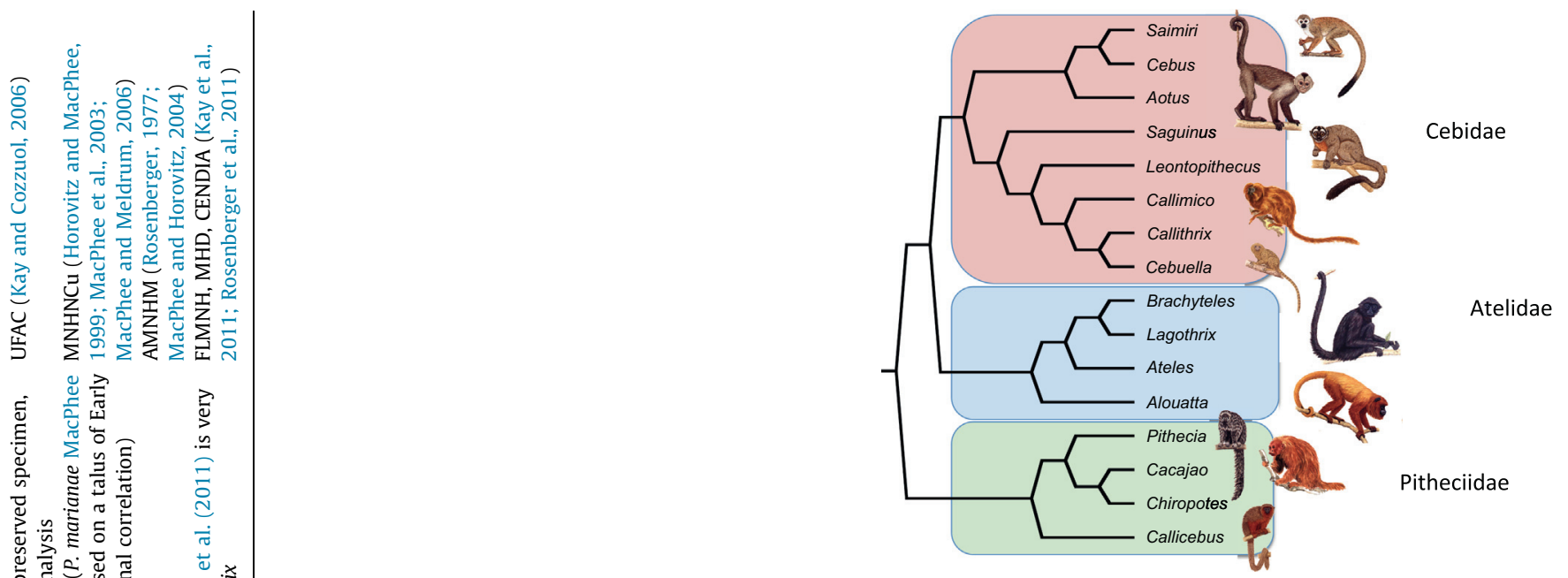

Fig. 1. Cladogram of extant platyrrhines at the generic level based on molecular sequence and SINE data (Ray et al., 2005; Opazo et al., 2006; Schrago, 2007; Hodgson et al., 2009; Osterholz et al., 2009; Wildman et al., 2009). The reconstructed position of Aotus differs from other molecular studies (Schrago, 2007; Perelman et al., 2011; Springer et al., 2012) that place Aotus it at the base of callitrichines rather than cebines.

any greater apparent similarity to the molecular tree (Fig. 1). In practical terms, this is interpreted to mean that a phylogenetic analysis of fossil platyrrhines based on craniodental or postcranial characters alone or separately may yield conflicting results. Extinct platyrrhine taxa, for which we have dental, cranial, and postcranial evidence, have the highest likelihood of yielding a phylogenetically reliable interpretation. From Table 1, those taxa are Early Miocene Homunculus from Argentina, Middle Miocene Cebupithecia from Colombia, and Pleistocene-Recent Antillean Paralouatta, Xenothrix, and Antillothrix. In what follows I use the combined morphological dataset, mindful of the possible complications arising from missing data in the fossils.

\subsection{Morphological and molecular phylogenies}

Fig. 3 compares the results of a combined morphological dataset, unconstrained by a molecular scaffold, with that of the molecular tree. The morphological data yields a broadly similar cladogram to that of the molecular but there are many significant differences, especially at deeper nodes. The molecular tree gives three families of extant platyrrhines, Cebidae and Atelidae with their outgroup Pitheciidae (Fig. 3A). Cebidae in turn consists of two clades - Callitrichinae and Cebinae. The most parsimonious morphological tree (Fig. 3B) finds three clades corresponding more or less to Pitheciinae, Callitrichinae, Atelidae, and a forth consisting mainly of Cebinae. Many points of disagreement are observed amongst which the most significant are: (1) the branching pattern among the atelids is widely divergent; (2) Callicebus falls within the Cebidae; (3) Callimico is sister to all other callitrichines and (4) atelids are the sister group to cebids and pitheciids.

\subsection{Fossil platyrrhines}

In the analysis of extinct taxa, I utilize a molecular scaffold with 16 extant platyrrhine taxa and three catarrhine taxa. Table 1 lists the taxa discussed, their ages and locations; see also Fig. 4. The phylogenetic findings are depicted in Fig. $5 \mathrm{~A}-\mathrm{C}^{3}$

\footnotetext{
3 The results of an unconstrained analysis yield a very similar pattern: taxa identified as stem platyrrhines using the molecular scaffold also are identified as such in the analysis that does not utilize a molecular scaffold.
} 


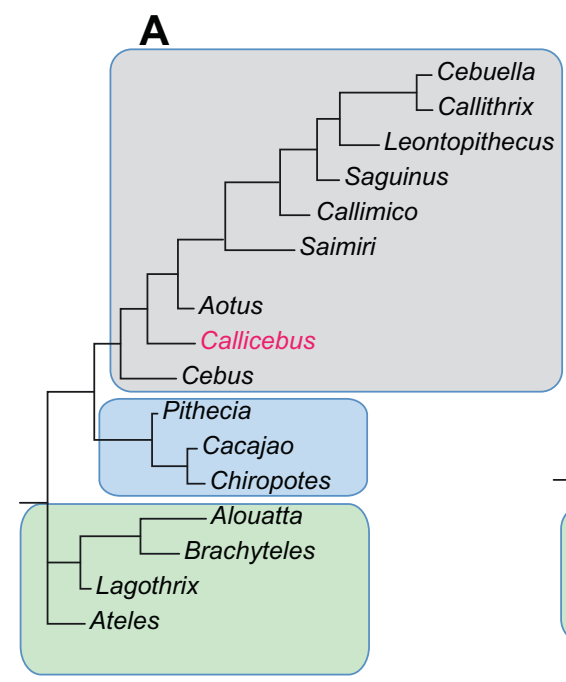

B

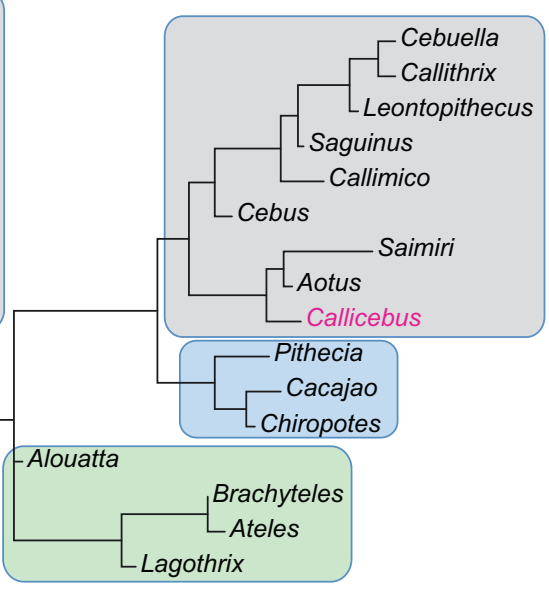

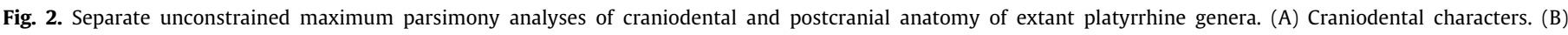

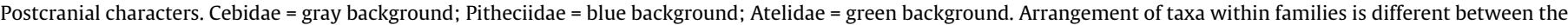

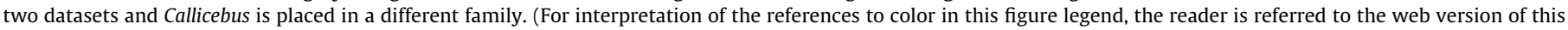
article.)
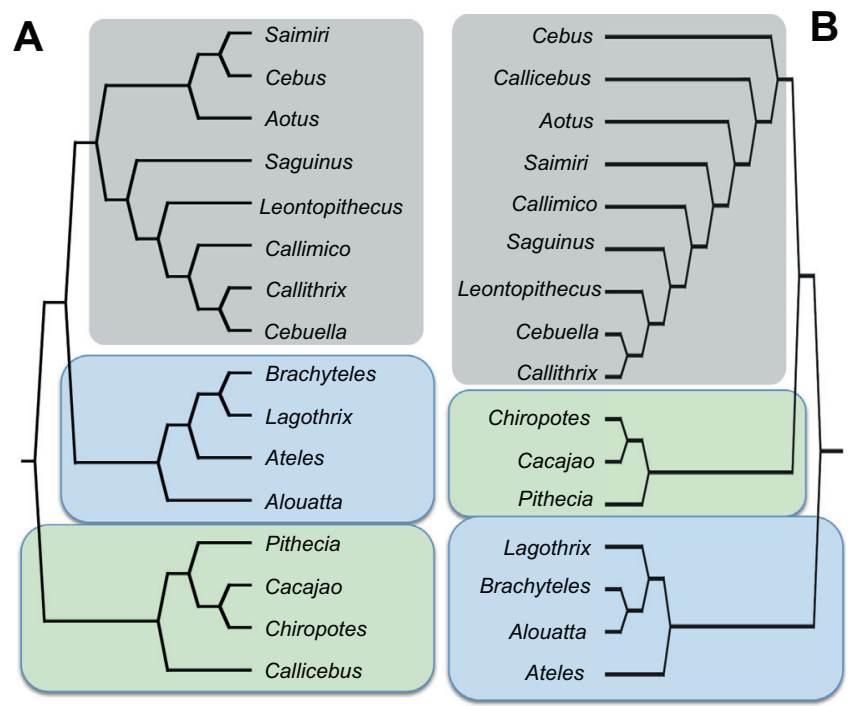

Fig. 3. (A) Molecular tree (with Aotus shown as the sister group to Saimiri and Cebus). (B) Maximum parsimony analysis of the combined morphological dataset (craniodental and postcranial characters) unconstrained by a molecular scaffold. Color scheme Cebidae $=$ gray background; Pitheciidae $=$ green background; Atelidae = blue background. There are 296 parsimony-informative characters. The maximum parsimony tree has a branch length of 102,709 with a $\mathrm{CI}$ of 0.32 , RI of 0.53 and a HI of 0.68 . By comparison the tree constrained with the molecular scaffold has a branch length of 105,448 with a CI of 0.312 , a RI of 0.514 , and a HI of 0.688 . Arrangement of taxa within families is different between the two datasets and Callicebus is placed in a different family.

The following are salient observations about the pattern of platyrrhine evolution based upon this analysis.

\subsubsection{Platyrrhine origins}

The phylogenetic analysis suggests that platyrrhines originated in Africa, an unremarkable finding not disputed by paleontologists (Fig. 5A, see also analyses including a broader spectrum of Middle Eocene-Oligocene early anthropoids, e.g., Kay et al., 2004c). Amongst those taxa of late Middle Eocene through Early Oligocene anthropoids included as outgroups in this study, Early Oligocene Aegyptopithecus and the parapithecids Apidium and
Simonsius are recognizably stem catarrhines whereas Catopithecus and Proteopithecus of the Late Eocene are stem anthropoids. None of these taxa seems to have any special relationship with Platyrrhini contrary to the interpretations of Hoffstetter (1977) or Takai et al. (2000) that Apidium or Proteopithecus, respectively, might be a sister taxon to platyrrhines. Several phylogenetic analyses (Kay et al., 2004b,c; Marivaux, 2006; Seiffert, 2006; Kay, 2012) do not support a recent suggestion (Chaimanee et al., 2012) that the late Middle Eocene Amphipitheciidae of South Asia might belong to the Catarrhini. The last common ancestor of platyrrhines and catarrhines must predate the first appearance of parapithecids at $\sim 37 \mathrm{Ma}$ (Seiffert, 2006). My phylogenetic analysis places Proteopithecus and Catopithecus (Late Eocene, Africa) as stem anthropoids, not catarrhines, but a similar divergence time would pertain if Catopithecus is a stem catarrhine, as suggested by Seiffert et al. (2005).

Despite the absence of clear synapomorphies, the cranial and dental anatomy of Late Eocene African taxa is very close to what we might expect the last common ancestor of platyrrhines and catarrhines to have looked like (Seiffert et al., 2005; Seiffert, 2006; Kay et al., 2008b; Williams et al., 2010). This casts doubt on a scenario of dispersal by primates and rodents to South America in Late Cretaceous times (Heads, 2010).

\subsubsection{Stem platyrrhines}

A word is needed here to clarify the status of the latitudinal distributions and biogeographical interpretations in what follows. Although South America and Africa have continued to drift apart over the past 40 million years, most of this movement has been rotational; South America has moved slightly northward, up to $5^{\circ}$ of latitude, so if anything, the present latitudes of Oligocene and Miocene fossil localities may have been somewhat farther south than those of today (Kay et al., 2012b). Shifting southerly distributions mentioned below are more likely to be accounted for by global and regional climatic factors such as the rise of the Andean cordillera and the extent of marine transgressions, ${ }^{4}$ rather

\footnotetext{
${ }^{4}$ A marine transgression occurs when sea level rises and seas move onto the continent; a regression is the recession of such seas.
} 
than a movement of the continent as a whole through relatively static climatic zones.

Stem platyrrhines are taxa in the platyrrhine clade that branched off before the last common ancestor of extant platyrrhines, i.e., extinct species that diverged after the platyrrhines and catarrhines diverged but are sister to crown platyrrhines. Stem platyrrhines form three distinct geographic clusters - (1) Late Oligocene mid-latitude taxa, (2) Early Miocene far-southern taxa, and (3) Early Miocene to Holocene taxa from the Greater Antilles.

3.3.2.1. Late Oligocene mid-latitudes. Presuming that the time of cladogenesis of platyrrhines from catarrhines was greater than 37 million years ago, and possibly as ancient as $45 \mathrm{Ma}$ (Seiffert, 2006) (Fig. 5A), then there is an unrecorded temporal interval of $>11$ million years in platyrrhine evolution before the first record of a platyrrhine, Branisella boliviana in the Salla Formation, Bolivia in the Late Oligocene, Deseadan Land Mammal Age $^{5}$ at about $26 \mathrm{Ma}$ (Kay et al., 1998b). The present analysis agrees with the commonly held view that Branisella is a stem platyrrhine (e.g., Takai et al., 2000; Fleagle and Tejedor, 2002) albeit highly specialized one (Kay et al., 2002). Although the Branisella fossil level today is above $3500 \mathrm{~m}$ in elevation, it was probably deposited when this region was at an altitude of less that $500 \mathrm{~m}$ and was continuous with lowlands of the Amazon basin (Hernández et al., 2005).

Primates are conspicuously absent in Late Oligocene Deseadan faunas in Patagonia. These faunas are well known through the recovery of thousands of specimens from many localities, and many mammalian genera occur in both low- and high-latitude Deseadan faunas (MacFadden et al., 1985). I interpret this to mean that climatic conditions, rather than incomplete sampling or geographic barriers account for the absence of platyrrhines from the Late Oligocene high latitudes. Deseadan platyrrhines seem to have been restricted to the present-day tropical and subtropical regions of the continent. The absence of primates in the Late Oligocene site of Tremembé, Brazil at $\sim 22^{\circ} \mathrm{S}$, despite a humid and warm climate (Veiga, 2009; but see Bershaw et al., 2010) is probably due to limited fossil recovery of fossil specimens, as also is case for the poorly known Santa Rosa fauna (Oligocene, western Amazon Basin) (Campbell, 2004).

3.3.2.2. Early Miocene platyrrhines from the high latitudes. The current southerly limit to the distribution of platyrrhines is $\sim 32^{\circ} \mathrm{S}$ across the eastern lowlands of Brazil, Argentina, and Paraguay (Fig. 5A). By contrast, until very recently, all primate-bearing fossil localities from the interval of $<26 \mathrm{Ma}$ to $<15.7 \mathrm{Ma}$ (roughly corresponding to the temporal limits of the Early Miocene) were recovered south of the distribution of extant primates (Table 1, Fig. 4). In Chile, Early Miocene Chilecebus ( $21 \mathrm{Ma}$ ) comes from $\sim 34^{\circ}$ South. Contemporaneously in Argentina, Early Miocene taxa including Mazzonicebus, Tremacebus, and Dolichocebus, and younger Early Miocene Homunculus, Soriacebus, and Carlocebus (18-16.5 Ma) come from between $39^{\circ}$ and $52^{\circ} \mathrm{S}$. As in other parts of the world, it is evident that the Early Miocene subtropical climates extended into higher latitudes (Zachos et al., 2001).

The high-latitude Miocene platyrrhines are comprised of stem forms in the present analysis, that is, outside the crown clade of Platyrrhini, although they do not necessarily form a clade of their own (Fig. 5A,C).

\footnotetext{
${ }^{5}$ Here and elsewhere, I refer to South American Land Mammalian Ages. These are faunal 'ages', including: Deseadan (Late Oligocene, 24-30 Ma; Colhuehuapian (Early Miocene, 20-21 Ma,), Santacrucian (Early Miocene, 19-15 Ma), Laventan (Middle Miocene, 13.6-12 Ma), Huayquerian (Late Miocene, 9-6.5 Ma) (Madden et al., 1997; Ré et al., 2010; Fleagle et al., 2012; Dunn et al., 2013).
}

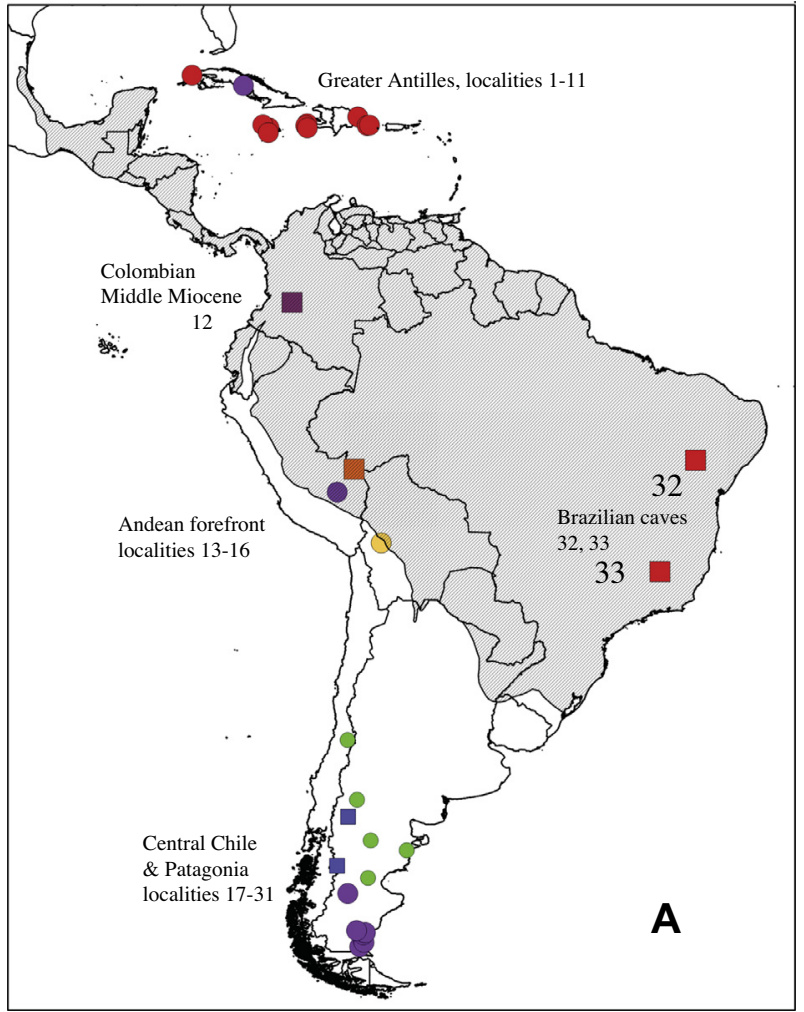

Fig. 4. Central and South American fossil localities with primates. (A) Platyrrhine fossil localities mapped against the current limits of distribution of living platyrrhines (shaded regions of South and Central America). (B) Detail of Caribbean and west central South American localities. (C) Detail of Chilean and Argentine localities. The shape of the symbol reflects whether the taxa found at the locality are stem platyrrhines (3) or crown platyrrhines (5)). Color scheme reflects geologic age as follows: red 0 : Pleistocene/Holocene (<1 Ma); orange late Miocene (6-9 Ma); magenta , Middle Miocene (12-14 Ma); blue $\bigcirc$, early Middle Miocene ( 15$16 \mathrm{Ma}$ ); purple , late Early Miocene (16.5-18.6 Ma): green $\mathrm{O}$, Early Miocene (20$21 \mathrm{Ma}$ ); yellow , Late Oligocene (26 Ma). Numbered localities are as follows: 1, Viñales, Cuba; 2, Domo de Zaza, Cuba; 3, Coco Ree Cave, Jamaica; 4, Sheep Pen and Long Mile caves, Jamaica; 5, Jackson Bay caves, Jamaica; 6, Trouing Lanj Genti, Haiti; 7, Trouing Jérémie No. 5, Haiti; 7a, Trou Jean Paul, Haiti; 8, Trou Woch Sa Wo, Haiti; 9, east of Rio Naranjo Abajo, Dominican Republic; 10, Padre Nuestro and La Jeringa caves, Dominican Republic; 11, Cueva de Berna, Dominican Republic; 12, La Venta, Tatacoa Desert, Colombia; 13, Patos and Bandeira, upper Río Acre, Brazil; 14, Atalaya, Fm. Madre de Dios, Peru; 15, Salla, Bolivia; 16, Río de las Leñas, Abanico Formation, Chile; 17, Barda Negra Hill, Neuquen, Argentina; 18, Cañadon del Tordilo, Neuquen, Argentina; 19, Sacanana, Chubut, Argentina; 20, Gaiman, Chubut, Argentina; 21, Río Cisnes, Chile; 22, Gran Barranca, Chubut, Argentina; 23, Cerro de los Monos, Santa Cruz, Argentina; 24, Lloma Lluvia, Santa Cruz, Argentina; 25, Portezuelo Sumich Norte, Santa Cruz, Argentina; 26, Premieras Barrancas Blancas, Santa Cruz, Argentina; 27, Monte Leon, Santa Cruz, Argentina; 28, Cerro Observatorio, Santa Cruz, Argentina; 29, Rincón del Buque Santa Cruz, Argentina; 30, Estancia La Costa and Puesto Ea. La Costa, Santa Cruz, Argentina; 31, Killik Aike Norte, Santa Cruz, Argentina; 32, Toca da Boa Vista, Bahia, Brazil; 33, Lagoa Santa, Minas Gerais, Brazil. (For interpretation of the references to color in this figure legend, the reader is referred to the web version of this article.)

3.3.2.3. Platyrrhines of the Greater Antilles. A number of extinct platyrrhines also have been described from the geologically young (Pleistocene-Holocene) cave deposits of the Greater Antilles, including Paralouatta (Cuba), Xenothrix (Jamaica) and Antillothrix (and possibly Insulacebus) from Hispaniola. As with other Antillean mammals, some of these species may have survived until the arrival of humans at about six thousand years ago (Steadman et al., 2005; MacPhee, 2009; Kay et al., 2011). In the phylogenetic analysis (Fig. 5B) these taxa also are stem taxa, although they are bracketed between the Patagonian primates mentioned above and the crown platyrrhine clade. This analysis yields a different pattern from that of Horovitz and MacPhee 

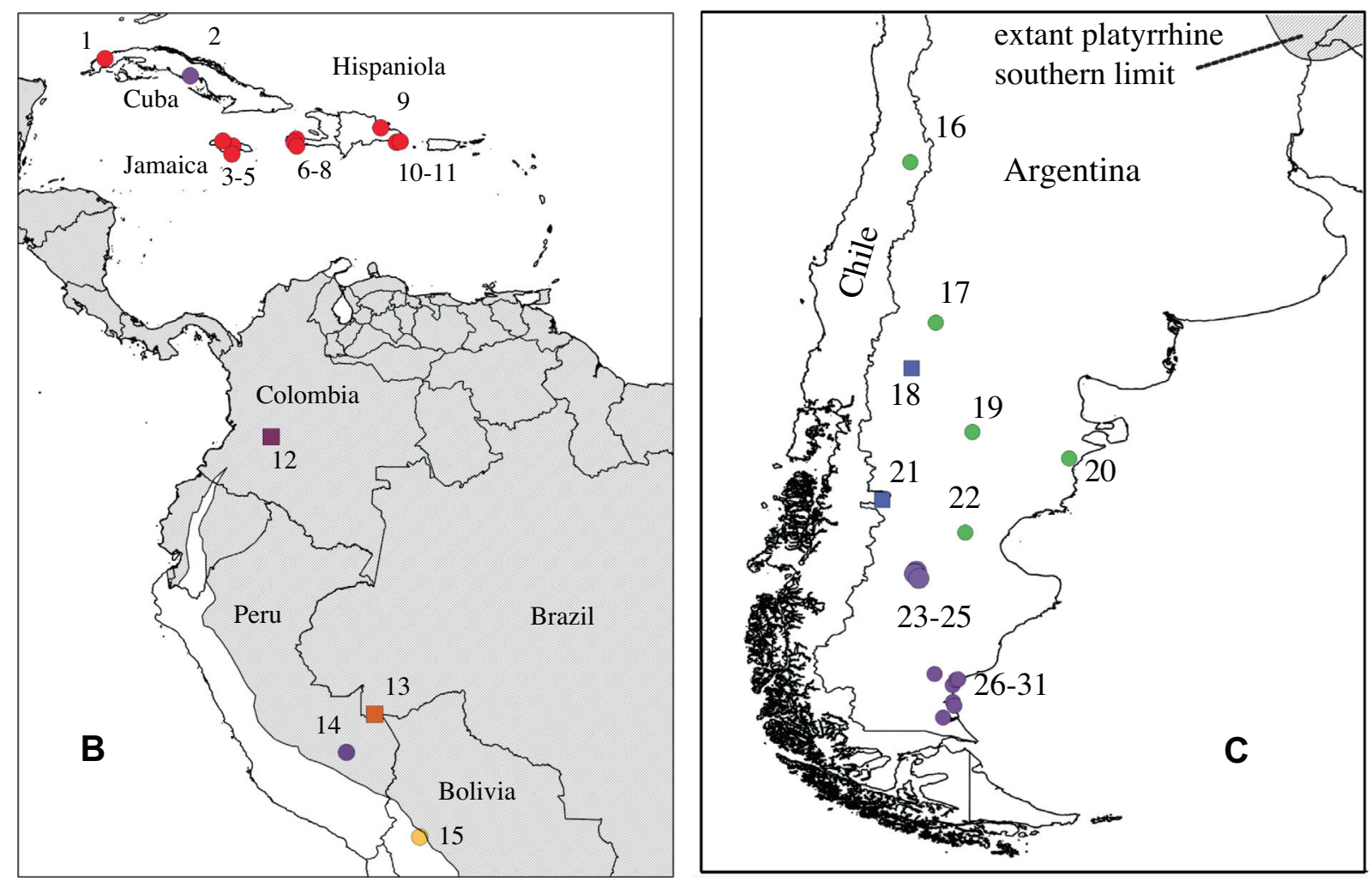

Fig. 4 (continued)

(1999) who found that the Antillean platyrrhines were a monophyletic group positioned at the base of the Pitheciidae. The different result is not a surprise because we now have far more material of Antillean monkeys, and Horovitz and MacPhee used a smaller dataset including only 8 postcranial characters, none of which was scored for an Antillean species.

MacPhee and Iturralde-Vinent (1995) describe a platyrrhine ankle bone (talus) from the Early Miocene (17-18 Ma) of Cuba, which they nominally refer to the genus Paralouatta, otherwise known from Pleistocene-Holocene cave material (Horovitz and MacPhee, 1999).

\subsubsection{Crown Platyrrhines}

As already noted, I find no support for claims that Early Miocene Patagonian taxa are crown platyrrhines (see also Kay and Fleagle, 2010). I will digress here to comment on the reasons that my parsimony-based phylogeny conflicts with several prior reconstructions that recognize several Patagonian taxa within the crown platyrrhine clade.

Dolichocebus gaimanensis comes from Colhuehuapian levels (20-21 Ma) in Patagonia. It is known from a skull, teeth, and a talus. Whereas my analysis places Dolichocebus as a stem platyrrhine, others identify it as a cebine or more restrictively as a sister taxon to living squirrel monkeys (Saimiri) (Rosenberger, 1979, 1982, 2010). Identification of Dolichocebus as a cebine or Saimiri sister taxon is a major element supporting the 'long-lineage' hypothesis of platyrrhine cladogenesis wherein it is argued that the extant subfamilies of platyrrhines existed before 20 million years ago (Perez et al., 2013; Tejedor, 2013). In this case, and accepting the cladogenetic pattern in Fig. 1, if 20 Ma Dolichocebus is the sister taxon to Saimiri, then the crown families Atelidae and Pitheciidae would already have appeared, as would the callitrichines, Aotus and even Cebus. In the case of Dolichocebus the proposed Saimiri link is based upon a few purportedly distinctive characters of the single known skull: an elongate head, a fenestrated interorbital region, gracile zygomatic arches, and the 'domed' profile of the frontal bone, none of which is preserved in the fossil skull (Kay et al., 2008a; Kay and Fleagle, 2010). The present phylogenetic analysis suggests that Dolichocebus is a stem platyrrhine.

Colhuehuapian Tremacebus is a second taxon claimed to reveal a deep divergence among the platyrrhine subfamilies. The taxon is based on a skull from $\sim 20$ million year old deposits in Patagonia. It is proposed that Tremacebus is the sister group of Aotus because the two share an unusually large orbit (Fleagle and Rosenberger, 1983; Rosenberger and Tejedor, 2013). The orbits of Tremacebus, while large, are not as large as those of Aotus (Kay et al., 2004a) and the present analysis based on a larger set of cranial characters supports the conclusion that Tremacebus is a stem platyrrhine ${ }^{6}$ (see also Kay et al., 2008a).

Soriacebus (early Santacrucian, $\sim 18-19 \mathrm{Ma}$ ) is a third early Patagonian platyrrhine that often is considered to be related to a crown platyrrhine family, in this case the Pitheciidae based on the procumbent shovel-like arrangement of the lower incisors, enlarged canines, and a lower jaw that deepens under the cheek teeth (Rosenberger, 2000, 2002; Fleagle and Tejedor, 2002). Recovery of Mazzonicebus from a Colhuehuapian locality extends the Soriacebus lineage back to 20-21 Ma. The alternative supported by broader functional and phylogenetic analyses is that Mazzonicebus and Soriacebus are a stem platyrrhine that exhibited adaptive convergence on a nut- or seed-eating diet (Kay, 1990, 2010; Kay et al., 2013).

\footnotetext{
${ }^{6}$ Hershkovitz (1974) similarly argues for a stem position of Tremacebus, but based an important component of his argument on the supposed 'prosimian grade' incompleteness of the postorbital septum separating the orbit from the tempora fossa. It is now generally agreed that the postorbital septum was likely broken and the inferior orbital fissure was not enlarged.
} 


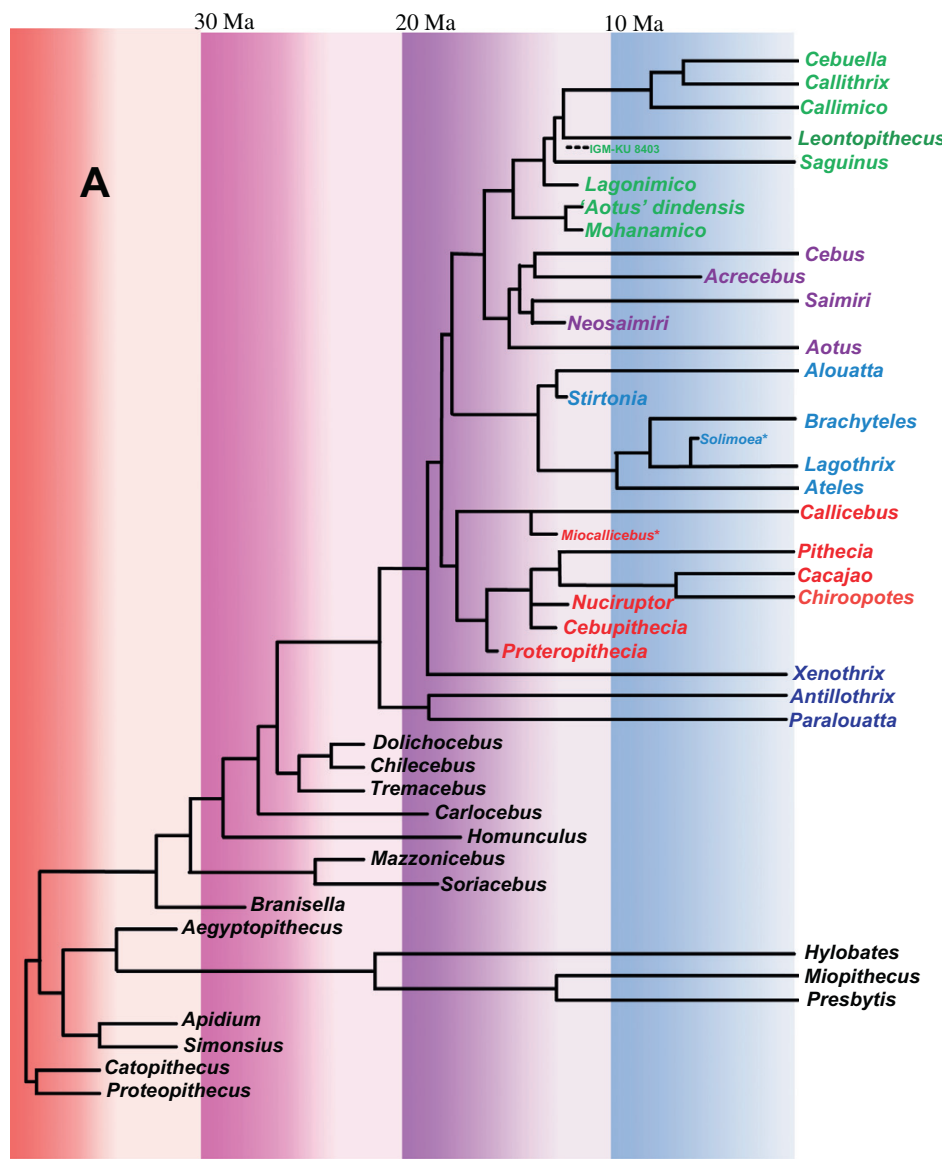

B
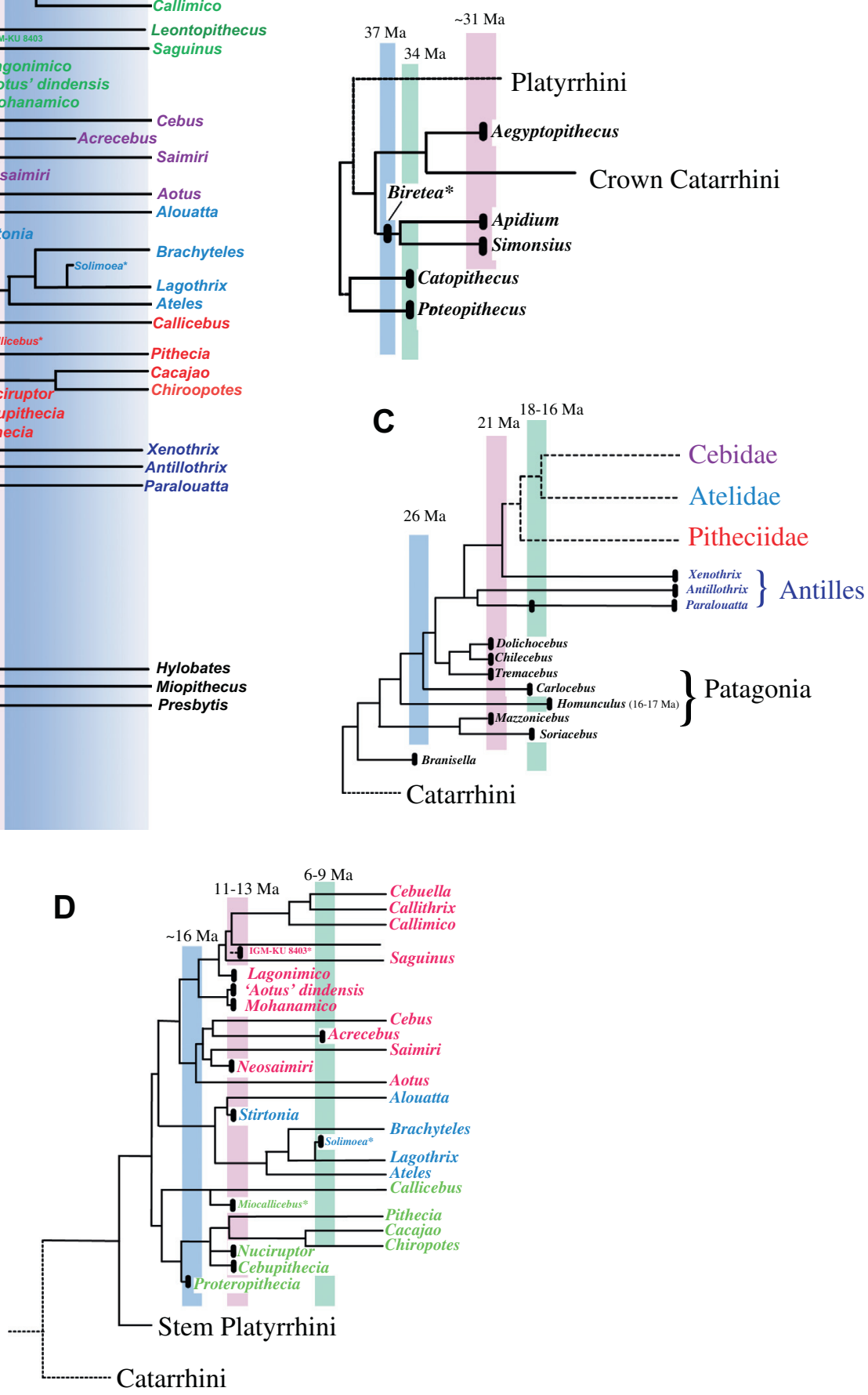

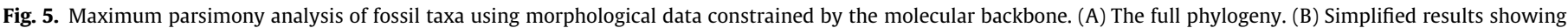

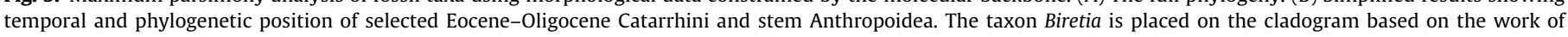

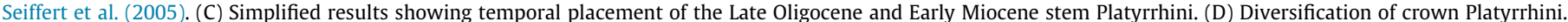

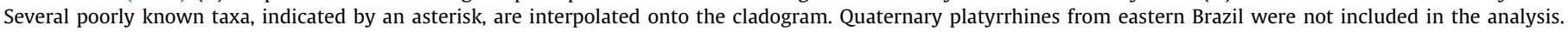

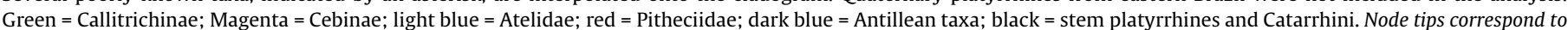

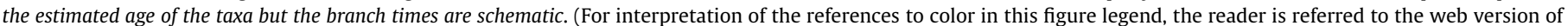
this article.)

The greater antiquity of crown platyrrhines may yet be established as more fossils are recovered in the tropical regions of the continent, as suggested by finds of Middle Eocene rodents and Early Miocene primates in Peruvian Amazonia (Antoine et al., 2012). But crown platyrrhines evidently were not present in the Early Miocene of Patagonia; they first appear in northern Patagonia in the Middle Miocene ( $<15.7 \mathrm{ma}$ ) and are recorded in abundance in the Amazon Basin by about 13.6 Ma.

The Middle Miocene fossil fauna of La Venta, Colombia, referred to below as the La Venta fauna, is found in the central Magdalena Valley, separated from the Amazon and Orinoco Basins by the eastern Cordillera of the Andes. However, evidence from fossil fishes 
and geomorphology indicates that in the Middle Miocene the eastern Cordillera had not yet uplifted sufficiently to produce a barrier to vertebrate dispersal between these three watersheds (Lundberg et al., 1986; Hoorn et al., 1995). Thus, the La Venta fauna was not geographically separate from the Amazon-Orinoco Basins between 13.5 and $12.2 \mathrm{Ma}$. All three families of living platyrrhines are recognizable at La Venta.

A. Pitheciidae. The extant family Pitheciidae includes two subfamilies, the Pitheciinae (the sakis and uakaris) and their sister taxon Callicebinae. The earliest record of crown platyrrhines appears in the Middle Miocene of Argentina in faunas collectively referred to as the late Santacrucian ('Colloncuran') from Neuquen Province in northern Patagonia with an age of $<15.7$ Ma. The taxon Proteropithecia represents a stem pitheciine, e.g., sister to the extant Pithecia, Chiropotes and Cacajao (Kay et al., 2013) (Fig. 6C). Therefore, the divergence of the Callicebus lineage must have occurred before $\sim 16$ million years ago, although a representative of the Callicebus clade, Middle Miocene Miocallicebus (13.213.9 Ma), does not appear until several million years later in the Magdalena region of Colombia (Takai et al., 2001). The Colombian Middle Miocene also records several other stem pitheciines, Cebupithecia (13.0-13.6 Ma) and Nuciruptor (12.4-12.8 Ma) (Meldrum and Lemelin, 1991; Meldrum and Kay, 1997; Kay and Fleagle, 2010).
As Proteropithecia is a stem member of the Pitheciinae, the more basal divergences within the families Pitheciidae leading to Callicebinae (and, also to the other platyrrhine families Atelidae and Cebidae) must already have occurred before $15.7 \mathrm{Ma}$. There are hints that crown platyrrhines were already present in the tropics of South America somewhat earlier. Atalaya, an Early Miocene (16-17 Ma) locality in Peruvian Amazonia (Fig. 4B) has yielded a recently described talus of a callitrichine-sized anthropoid that may be a crown platyrrhine (Marivaux et al., 2012).

B. Atelidae - Atelidae is represented by Stirtonia spp., a common platyrrhine from La Venta, Colombia (12.8-13.6 Ma) (Hershkovitz, 1970; Kay et al., 1987). Stirtonia evidently is sister to Alouatta, although some analyses link it with Brachyteles, no doubt owing to the convergent similarities of the masticatory apparatus between howlers and muriquis on account of their folivorous diets (Zingeser, 1973; Anthony and Kay, 1993). A single tooth of Stirtonia of Huayquerian age (6-9 Ma) also is recorded in the upper Río Acre, western Amazonia (Kay and Frailey, 1993; Negri et al., 2010). From Bandeira near Patos comes Solimoea, poorly known but probably representing the earliest appearance of the Lagothrix clade at 69 Ma (Kay and Cozzuol, 2006). Other occurrences of fossil atelids (Protopithecus, Caipora) are from Pleistocene-Holocene Brazilian cave deposits (Fig. 5A). The latter occurrences establish that the Atlantic forests had a greater species richness in the recent past,

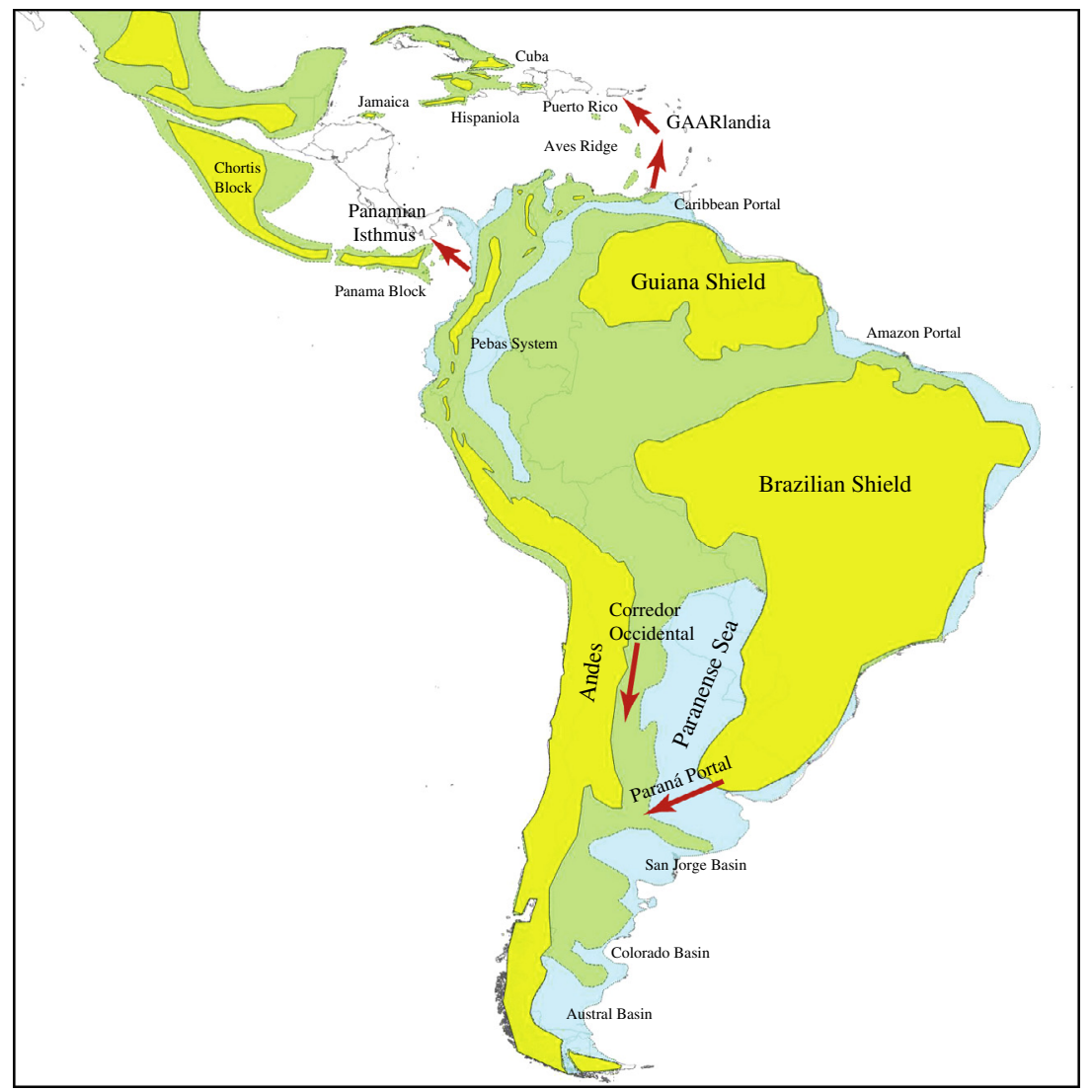

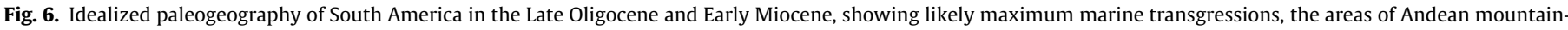

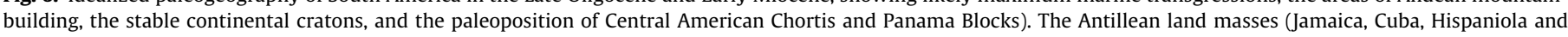

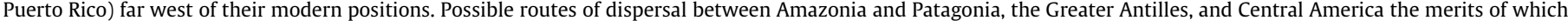

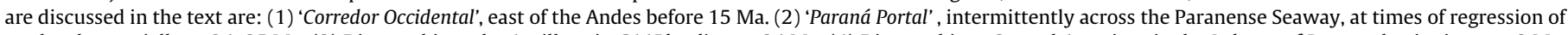

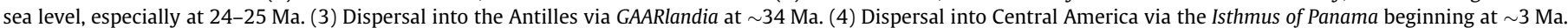

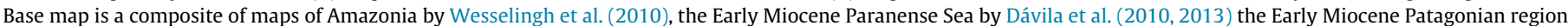

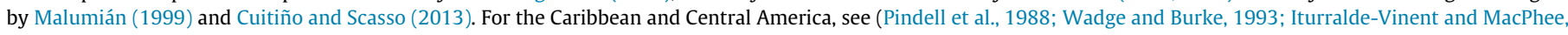

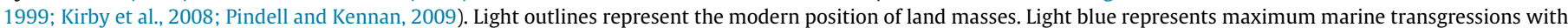
a range of marine to mainly freshwater conditions. Green color is lowland 0-200 m; yellow, upland (>200 m). 
but do not resolve the timing of cladogenesis within Atelidae (Hartwig, 1993; Cartelle and Hartwig, 1996; Hartwig and Cartelle, 1996; Jones, 2008).

C. Cebidae - The extant family Cebidae includes two subfamilies, the Cebinae (Cebus, Saimiri and Aotus) and the Callitrichinae (tamarins and marmosets). Fossil cebines are represented in the Laventan Neosaimiri fieldsi (12.0-13.2 Ma). In his initial description, Ruben A. Stirton noted the close relationship between Neosaimiri and Saimiri (Stirton, 1951). Indeed, it has since been argued that Neosaimiri should be considered congeneric with Saimiri (Rosenberger et al., 1991a) although this view is not widely accepted (Takai, 1994; Hartwig and Meldrum, 2002). Laventiana annectens from the same stratigraphic level as N. fieldsi was proposed as a transitional form between Saimiri and Cebus (Setoguchi et al., 1990; Rosenberger et al., 1991c). Recovery of additional fossil material does not support its specific distinctness from $N$. fieldsi nor its status as a linking form (Takai, 1994; Kay and Meldrum, 1997).

A poorly known cebine Acrecebus comes from the western Amazon basin from sediments of Late Miocene (6-9 Ma) (Kay and Cozzuol, 2006; Negri et al., 2010). Acrecebus is most likely sister to Cebus. It is notable for its very large size (probably $>15 \mathrm{~kg}$ ).

The record of the Aotus lineage is highly contentious. I have already discussed the status of Tremacebus as a stem platyrrhine, not a close relative of Aotus. It is generally accepted that a species of Aotus, A. dindensis, occurs at La Venta (Setoguchi and Rosenberger, 1987; Hartwig and Meldrum, 2002). This conclusion is supported by the suggestion that $A$. dindensis, like extant owl monkeys, had a large orbit and may have been nocturnal. A word of caution is that one $A$. dindensis specimen preserves only a small part of the orbit and no part of the orbital rim, so orbit size is difficult to estimate (Kay et al., 2004a). In 1990, I concluded that the taxon Mohanamico hershkovitzi from the same Middle Miocene locality as $A$. dindensis is probably the same species (Kay, 1990); my interpretation has not received support from most paleontologists. In the present analysis, I find that "A." dindensis and Mohanamico are closely related sister taxa (arguably the same genus and species). Also, the 'A.' dindensis-M. hershkovitzi clade links with stem callitrichines (not pitheciines, as I had claimed hitherto (Luchterhand et al., 1986)). In short, no known fossil species is linked with the Aotus lineage.

Turning to Callitrichinae, we encounter a complete blank in the fossil record until the Middle Miocene at La Venta when two taxa, Lagonimico and Mohanamico (13.0-13.6 Ma) (with "Aotus dindensis") are placed as stem members of the Callitrichinae clade. Lagonimico is represented by a skull that has received attention owing to its large size (for a callitrichine) (Kay, 1994).

Two other Colombian Miocene taxa, Micodon and Patasola may possibly be callitrichines. The type specimen of Micodon kiotensis (Setoguchi and Rosenberger, 1985; Rosenberger et al., 1990b) is an eroded upper molar with most of its enamel missing that most probably is a specimen of Neosaimiri and does not pertain to Callitrichinae (Kay and Meldrum, 1997). An isolated upper lateral incisor and a lower fourth premolar (IGM-KU 8403, Fig. 5D) were referred to Micodon and probably represent the first record of crown Callitrichinae. The premolar resembles Leontopithecus in some respects (Rosenberger et al., 1990b). IGM-KU 8403 presents evidence for crown Callitrichinae, at $\sim 13 \mathrm{Ma}$. Patasola magdalenae is slightly older (13.4-13.6 Ma). It is represented by a single immature specimen (a lower jaw with deciduous teeth) that most likely is a crown callitrichine (as argued by Kay and Meldrum (1997)).

\subsection{Biogeographic scenario}

The clade Platyrrhini has existed since the later Middle Eocene, as evidenced by the platyrrhine/catarrhine divergence docu- mented in Africa by $37 \mathrm{Ma}$ or earlier (Seiffert, 2006). This implies the existence of a platyrrhine 'ghost' lineage of a minimum of 11 million years (37-26 Ma). The timing of dispersal of platyrrhines to South America is not well constrained. If they arrived with caviomorph rodents, another neotropical clade with its roots in Africa, the timing could have been earlier than 41 Ma when caviomorph rodents first appear in the neotropics (Antoine et al., 2012).

Platyrrhines first appear in the South American fossil record at $26 \mathrm{Ma}$. The first appearance is at $\sim 20^{\circ} \mathrm{S}$ at Salla, Bolivia. The Salla beds were then in the lowland and confluent with, or part of the proto-Amazon basin (Benjamin et al., 1987; Hernández et al., 2005). The occurrence is consistent with initial platyrrhine cladogenesis having occurred within the tropics.

The tropical regions of South America were by no means stable from the geological perspective. A summary is presented by Lundberg et al. (1998) and Wesselingh et al. (2010); see especially Plates 14-16 in Hoorn and Wesselingh (2010). Fig. 6 illustrates some of the major geographic features of South America in the Early Miocene ( 24-26 Ma). Some features like the Guyana and Brazilian continental upland shields persisted throughout the Cenozoic. Thus, the Atlantic Forest of southeastern Brazil would have remained relatively stable from a geological (although not necessarily climatic) perspective. Other features of the tropics were considerably more dynamic. At present, more than $90 \%$ of the South American tropical waters drain eastward to the Atlantic but this is a geologically recent phenomenon. Before the Late Miocene ( $\sim 9 \mathrm{Ma})$ most of the drainage was northward into the Caribbean via the Caribbean portal near the present mouth of the Orinoco River. A major drainage divide may have existed near Manaus in the central Amazon basin. Waters to the east of this divide drained eastward to the Atlantic; those west of the divide reached northward to the Caribbean. At about $10 \mathrm{Ma}$, the rise of the Eastern flank of the Colombia Andes separated the present Magdalena river basin from the Amazon drainage. Then at $\sim 8 \mathrm{Ma}$ the rise of a further geologic arch produced an Orinoco-Amazon divide. Orinoco waters continue to flow into the Caribbean but a 'modern' transcontinental Amazon drainage was newly established. Finally the rising Andes produced a foreland basin in western Amazonia that produced lakes and wetlands called the Pebas System. This system was connected to a Caribbean embayment that had fluctuating influence on its salinity.

These profound changes in the tropical part of the continent must have had significant vicariant effects on primate speciation in the Miocene, for the Amazon and its tributaries have long been known to be effective barriers to mammalian species dispersal (Ayres and Clutton-Brock, 1992; Colwell, 2000). ${ }^{7}$ Nevertheless, neotropical speciation events are inaccessible through want of a fossil record. On the other hand, a biogeographic scenario for dispersal out of the tropics is somewhat more accessible to paleontologists owing to the presence of an extra-tropical fossil record.

The following scenario for extratropical dispersal should be treated as a hypothesis consistent with available evidence about platyrrhine phylogeny and compatible with geologic evidence (Fig. 6). I consider the timing of three major dispersal patterns out of the tropics: (1) an Early Miocene southward expansion into Patagonia, (2) arrival of primates in the Greater Antilles, and (3) dispersal of crown platyrrhines into Central America.

\footnotetext{
7 This river barrier phenomenon was remarked upon by Alfred Russel Wallace (1852): "During my residence in the Amazon district ... I soon found that the Amazon, the Rio Negro and the Madeira formed the limits beyond which certain species never passed. The native hunters are perfectly acquainted with this fact, and always cross over the river when they want to procure particular animals, which are found even on the river's bank on one side, but never by any chance on the other. On approaching the sources of the rivers they cease to be a boundary, and most of the species are found on both sides of them".
} 


\subsubsection{The Paraná Portal: Early Miocene expansion and Middle Miocene extirpation in Patagonian}

Platyrrhines do not appear in the fossil record of Patagonia until about $21 \mathrm{Ma}$ and their first appearance in the high latitudes probably represented a real geographic range expansion and not a sampling artifact on account of rarity and taphonomic bias, for the Patagonian record of small and medium-sized mammals from older rocks of Deseadan Age $(24-30 \mathrm{Ma})$ is well documented, whilst primates are absent. Primates reached Patagonia during the interval between 24 and $21 \mathrm{Ma}$; the timing is hard to constrain further because the Patagonian fossil record is sparse or absent during this time interval.

Because all records of these Patagonian early platyrrhines represent stem forms, I propose that cladogenesis of crown platyrrhines was tropical and did not occur until after platyrrhines reached Patagonia. Alternatively, crown platyrrhine lineages had already appeared in the tropics but just one contemporaneous stem lineage reached the south. I tend to discount the latter possibility because Colhuehuapian Patagonian platyrrhines were already too diversified in diet, locomotion, and activity pattern to have evolved in situ. Also, the evidence is not compelling that Patagonian primates represent a single clade, suggesting that several lineages may independently have reached Patagonia in this time interval.

Patagonian platyrrhines did experience morphological change in some lineages. For example, Mazzonicebus ( 21 Ma) is a sister taxon and possible anagenic predecessor of Soriacebus ( $\sim 18 \mathrm{Ma}$ ). Overall there was a decline in known taxa from four genera in the Colhuehuapian to one in the Santcrucian; the stem platyrrhines disappear from Patagonia after about 16.6 Ma.

The South American history of Oligocene and Miocene climate change, the distribution of the mid-latitude dry belt, mountain building, and changes in eustatic sea level support the above scenario.

3.4.1.1. Climate. South America moved roughly $5^{\circ}$ northward during the Cenozoic, so drifting of the continent would have moved any particular locale passively through climatic zones only to a limited degree. Oligocene climatic conditions at southern latitudes were drier and cooler, less favorable for tropical or subtropical mammals (Zachos et al., 2001; Reguero et al., 2007). Beginning in the Miocene, about $23 \mathrm{Ma}$, global (and presumably Patagonian) climate became warmer (Fig. 7A) (Zachos et al., 2001). By 17 Ma global temperatures were as much as $4-5^{\circ} \mathrm{C}$ warmer than today. This interval, called the Mid-Miocene Climate Optimum (MMCO), punctuated a time of gradual cooling and growth of Antarctic ice sheets (Foster et al., 2012).

Even with Patagonian climatic conditions being more favorable for primates in the Early Miocene, a climatic filter continued to exist in the mid-latitude dry belt in western South America. At about 17-23 ${ }^{\circ}$ South, atmospheric and Pacific oceanic circulation systems cause upwelling of cold water leading to low evaporation and low precipitation along the west coast of South America. This system was established as far back as the Mesozoic (Strecker et al., 2007), and has produced semi-arid conditions (rainfall $\leqslant 800$ $\mathrm{mm} /$ year) in this region of the continent over the past 65 million years (Garreaud et al., 2010). Semi-arid climates would tend to support short or scrubby vegetation with few trees, presumably a climate barrier to the southward spread of platyrrhines and other forest-dependent species. The oxygen isotope record from the Salla Formation in Bolivia reflects semi-arid conditions at $26 \mathrm{Ma}$ (Bershaw et al., 2010), consistent with the unusually high-crowned wear-resistant cheek teeth of the Salla primate Branisella (Kay et al., 2002).

At similar latitudes in eastern South America today, climate conditions are much wetter ( $>1000 \mathrm{~mm}$ per annum) and primates
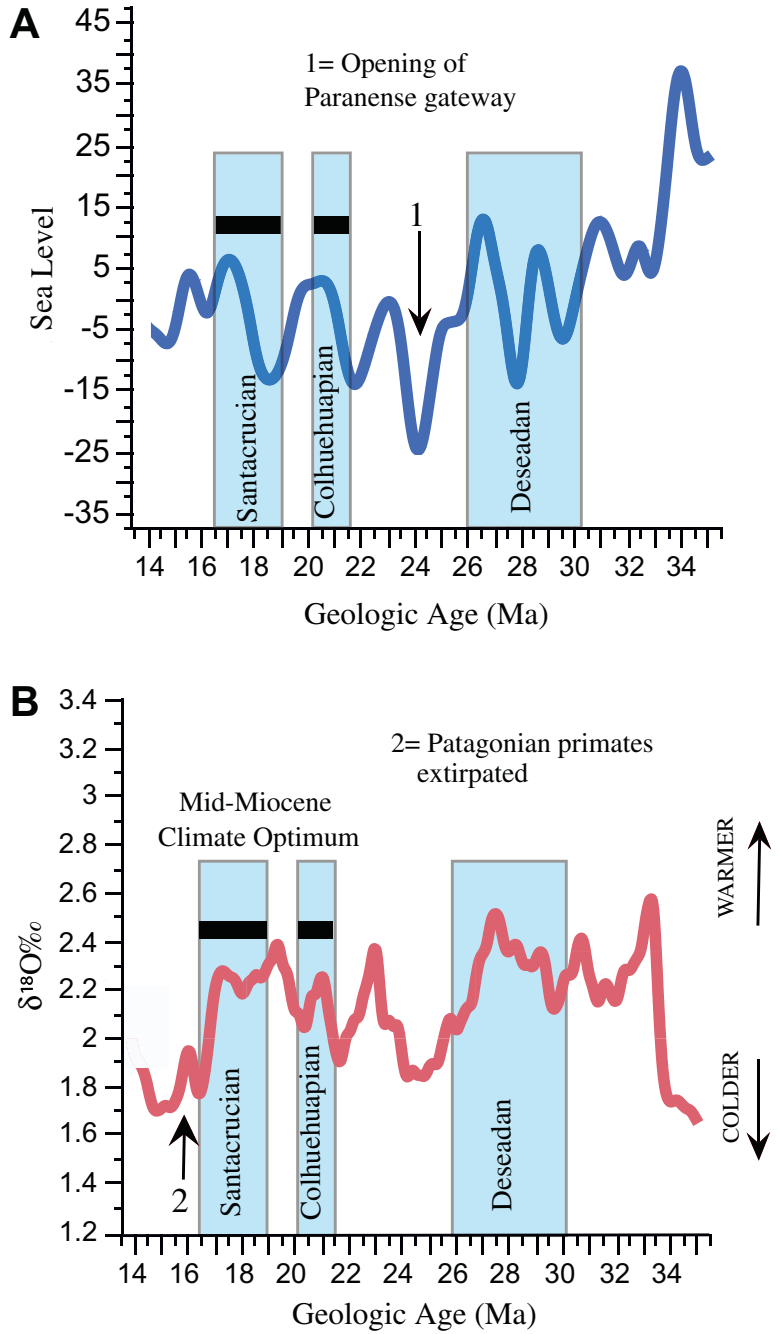

Fig. 7. Global climate and eustatic sea level changes between 35 and $14 \mathrm{Ma}$ (Oligocene-through earliest Middle Miocene). (A) Global fluctuation of sea level. A precipitous fall in sea level at about $24 \mathrm{Ma}$ (arrow at ' 1 ') would have produced regression of the Paranense Sea and removed a significant barrier to faunal exchange between subtropical South America and regions to the south. (B) Fluctuating levels of ${ }^{18} \mathrm{O}$ in parts per million serve as a proxy for temperature. Increased ${ }^{18} \mathrm{O}$ is associated with climate warming. Arrow at ' 2 ' indicates the termination of the Mid-Miocene Climatic Optimum with rapid global cooling and the extinction of platyrrhines in Patagonia. Sea level data from Miller et al. (2005); Oxygen isotope data from Zachos et al. (2001).

exhibit greater species richness and extend their ranges farther south than in the west. Thus, the dry belt would have been more persistent and extreme in Bolivia and western Paraguay than in southeastern Brazil and Missiones Province, Argentina.

3.4.1.2. Mountain building. During the Oligocene and Miocene, no major changes in elevation occurred in eastern mid-latitudes (17-23 South) over the Brazilian Shield and precipitation would have been sufficiently high, as it is today, to sustain forests with primates. However, Andean uplift on the western margin of the continent at the same latitude belt, progressively added a barrier to primate dispersal. In the Late Oligocene, uplift was moderate and the Andean plateau (Altiplano), which today exceeds $3500 \mathrm{~m}$ elevation, was probably at less than $1000 \mathrm{~m}$ and would not have served as a major dispersal for mammals. By the Middle Miocene times the altitude of the Altiplano reached $\sim 2000 \mathrm{~m}$ (Hartley, 2003), which would certainly be an added barrier to the dispersal of primates at these latitudes. 
3.4.1.3. Sea-level changes. Eastern South America had a more stable altitudinal profile than in the west, so fluctuations in the size of the Paranense Sea likely reflect global sea-level fluctuation (Hernández et al., 2005). Such shifts would have served as a fluctuating barrier to mammalian dispersal. In the Late Oligocene, corresponding to the Deseadan Land Mammal Age, global sea level was particularly high (30-40 m above current levels; Fig. 7) (Miller et al., 2005). This globally high sea-stand may correspond to a marine transgression of the Paranense Sea producing the Laguna Paiva Formation which reached the Andean foothills at $25^{\circ} \mathrm{S}$ (Dávila et al., 2010; Dávila and Lithgow-Bertelloni, 2013). This transgression must have served as a potent barrier to mammalian interchange. By 25$24 \mathrm{Ma}$, however, sea levels fell to $20-40 \mathrm{~m}$ below current levels (Miller et al., 2005) with regression of the Paranense continental sea, opening an eastern corridor, the 'Paraná Portal', for dispersal between the central and southern parts of the continent.

In summary of the above (Figs. 6 and 7), until about $25 \mathrm{Ma}$, climatic conditions were unfavorable for primates in Patagonia, after which Patagonia became subtropical, culminating in the Mid-Miocene Climate optimum. After about $15 \mathrm{Ma}$, Patagonia rapidly became cooler and drier; primates and other climate sensitive taxa were regionally extirpated. Several possible corridors for southward Early Miocene dispersal are possible. To the west, Andean uplift at $\sim 20^{\circ} \mathrm{S}$ was not as high in the Early Miocene as it is today, but semi-arid conditions would have been unfavorable for primates. At these latitudes in the east, after having been particularly high in the Oligocene, sea levels fell in the Early Miocene opening a possible low-elevation corridor across the Paranense Sea into Patagonia between 25 and 24 Ma. What I will call the Paraná Portal Dispersal Corridor would always have been more favorable than in dispersal farther west through Paraguay and Bolivia on account of higher rainfall at these latitudes. ${ }^{8}$

Platyrrhine extirpation in Patagonia in the Middle Miocene was induced by some of the same factors mentioned above. Global climate cooling beginning in the Middle Miocene (Zachos et al., 2001) made this region increasingly unfavorable for subtropical mammals (Pascual and Ortiz Jaureguizar, 1990). By about 15 Ma, the rising Patagonian Andes produced major rain-shadow effects that increased Patagonian aridity (Blisniuk et al., 2005).

\subsubsection{The Antillean trap}

Most likely, platyrrhines reached the Greater Antilles from South America, as did most of the other terrestrial mammals in the region: Antillean sloths and rodents have well-established South American sister groups (MacPhee, 2005). Sloths are first recorded in the Early Oligocene of Puerto Rico ( $31 \mathrm{Ma})$; caviomorph (capromyid) rodents occur in the Early Miocene of Cuba ( $\sim 18 \mathrm{Ma})$ (MacPhee, 2005). It is possible that all these immigrants followed a path to the Antilles via Central America but a direct South American dispersal seems more likely on present evidence. Sloths and caviomorph rodents do not appear in the fossil record of Central and North America until much more recently than they do in the Antilles: sloths at about $9 \mathrm{Ma}$ and caviomorph rodents at $3.8 \mathrm{Ma}$ (Woodburn, 2010). The later arrival of sloths and caviomorph rodents in Central America than in the Greater Antilles is further evidenced by their absence from sites in the Early Miocene of Panama (Mac Fadden, 2006).

Antillean arrival of primates, like that of caviomorph rodents and sloths, had occurred by the Early Miocene based on an Early Miocene primate record in Cuba (MacPhee et al., 2003). A proposed Early Oligocene Antillean arrival of primates seems unlikely based on the phylogenetic bracketing of Antillean taxa between crown

${ }^{8}$ Tejedor (2013) refers specifically to such a western corridor called the "Corredor Paleobiogeográfico Occidental Sudamericano (CPOS)". platyrrhines and Patagonian stem species (Fig. 5A). Had platyrrhines been resident in the Antilles as far back as the Early Oligocene ( $\sim 34 \mathrm{Ma}$ ) and entered the region following a land bridge or a series of closely linked islands, as proposed in the GAARlandia hypothesis of Iturralde-Vinent and MacPhee (1999) (Fig. 6), one would have expected Antillean taxa to be stem species phylogenetically basal to both the Patagonian taxa and crown platyrrhines, not bracketed between them. A more westerly and more recent subarial Aves ridge could have provided an island chain for rodent and primate dispersal at $\sim 24-25 \mathrm{Ma}$ (Early Miocene), coincident with the Paranense regression mentioned above (Fig. 7). Nevertheless, the conspicuous absence in the Greater Antilles of a typical South American Miocene mammalian fauna (marsupials, litopterns, notoungulates, astrapotheres and armoured xenarthrans) discounts overland dispersal and favors over-water dispersal and does not require the assistance by ephemeral island chains.

The present analysis also suggests, albeit weakly, that Antillean taxa may be paraphyletic relative to crown platyrrhines. Jamaican Xenothrix is more closely related to crown platyrrhines than the Cuban-Hispaniolan Paralouatta/Antillothrix sister pair, hinting that there was more than a single migration event and that the event or events, occurred through 'waif' or 'sweepstakes' dispersal ${ }^{9}$ (see also a critique of the GAARlandia hypothesis by Hedges (2006)).

Whatever the case, the Antilles was an extinction trap: primates on the islands were extirpated in recent times, as were $>90 \%$ of all other terrestrial mammals. Holocene sea level rise and the arrival of Native Americans, separately or in combination, may be implicated (Steadman et al., 2005; MacPhee, 2009).

\subsubsection{Central America}

Primates existing in Central America today are closely related to taxa residing in northern South America. All are congeneric with South American relatives. Current evidence suggests that the ancestors of platyrrhines currently residing in Central America reached the area in three to four waves beginning with to the emergence of Isthmus of Panama at around $3 \mathrm{Ma}$ (Collins and Dubach, 2000; Cortés-Ortiz et al., 2003; Ford, 2006; Lavergne et al., 2010; Boubli et al., 2012; Morales Jimenez, this volume-b, this volume-a). If primates existed in Mesoamerica before $~ 3 \mathrm{Ma}$ it is clear that they did not leave any living descendants.

\section{Summary and conclusions}

Over the years there have been many claims made for a phylogenetic relationship between extinct platyrrhine taxa and extant species or clades. In most cases these proposals are based on a limited set of characters, or, in the case of the early literature, no organized assessment of characters at all. Given the high level of homoplasy in the morphological data, one can always pick and choose individual characters that support almost any phylogenetic proposal. And, because the morphological data from different anatomical systems yield significantly different phylogenies, the fragmentary nature of the fossil record weighs heavily on our interpretations.

My biogeographic scenario lends support for a relatively late divergence of crown platyrrhines. Tropical South America has been

\footnotetext{
${ }^{9}$ Paraphrasing Marshall (1988), a 'waif dispersal' (also called a 'sweepstakes dispersal') occurs across a water barrier during times of flooding when rafts of vegetation may break away from the banks of swollen rivers, carried to sea and moved by winds and currents to distant shores; upon successful docking, the voyagers disembark to colonize new lands (p. 381). As to the origin of the mammalian fauna of the Greater Antilles, Matthew (1919) states: "The only explanation that seems to me conformant with all the data, physiographic, geologic and faunal, is that the islands have been populated by colonization through storms and ocean drift without land connection with the continents. The mammals... would seem to be practically limited to ocean drift as a method of transportation (pp. 180-181)".
} 
a center for platyrrhine diversification since platyrrhines arrived on the continent in the middle Cenozoic.

Phylogenetic evidence supported by paleoclimatology, paleontology and geology suggests primates dispersed from tropical South America to Patagonia at $\sim 24$ Ma via the "Paraná Portal", a land connection through eastern South America across a retreating Paranense Sea. Persistent Cenozoic aridity and the accelerated uplift of the Andes in mid-latitudes makes a western portal less plausible.

Antillean primates appear to be stem forms phylogenetically bracketed between Patagonian stem platyrrhines and crown platyrrhines. Therefore, waif dispersal in the Early Miocene from northern South America into the Greater Antilles was more likely than a crossing via an earlier-occurring GAARlandia land bridge in the Early Oligocene ( $34 \mathrm{Ma})$.

Molecular evidence suggests crown platyrrhines arrived in Central America by crossing an intermittent connection through the Isthmus of Panama at or after 3.5 Ma. Neither Early Miocene Patagonian nor Pleistocene-Recent Antillean platyrrhines left living descendants or relatives.

It is probable that the crown platyrrhine clade did not originate before about 20-24 Ma, a conclusion consistent with the phylogenetic analysis of fossil taxa presented here and with the molecular clock estimates of Hodgson et al. (2009): mean = $19.5 \mathrm{Ma}$; $95 \%$ range $=16.8-23.4$; and Perez et al. (2013) (mtDNA, 'second hypothesis': mean $=24.3 \mathrm{Ma}, 95 \%$ range $=21.2-27.9$ ). The first definite evidence of crown platyrrhines is at $\sim 15.5 \mathrm{Ma}$, at which time crown cladogenesis was already well underway.

This scenario is subject to test and refinement as we learn more about Early Miocene platyrrhines from new recoveries in eastern Peru (Marivaux et al., 2012) and elsewhere in the tropics. A direct prediction will be that other mammals that are climatically sensitive to low temperature and rainfall and are dependant on forest biomes should share a similar evolutionary history.

\section{Acknowledgments}

I thank Jessica Lynch Alfaro for the invitation to contribute this paper and for her many suggestions and edits as well as those of two anonymous reviewers that improved the final version. The work builds on a series of Grants from NSF, National Geographic Society, and LSB Leakey Foundation beginning in 1981 for fieldwork in Colombia, Bolivia, Chile, and Argentina, and study of systematic collections of platyrrhines, especially at the Smithsonian Institution. High resolution CT imagery was undertaken at University of Texas and Pennsylvania State University, for which I thank the respective authorities. Recent work was supported by NGS and NSF Grants for research in Patagonia and the Dominican Republic BNS-1042794 and NSF BNS-0851272.

I thank my former colleague at Duke University, Richard $\mathrm{H}$. Madden for his scientific insight and generous collaboration. I am especially grateful for the assistance and collaboration of staff and faculty of Universidad and Museo de La Plata, especially Sergio Vizcaíno, M. Susana Bargo, M. Guiomar Vucetich, and Alfredo A. Carlini, I thank John Fleagle for his advice and help over the past 40 years. Blythe Williams read and discussed the findings of this paper and worked closely with me in the construction of the character-taxon matrix.

\section{Appendix A. Supplementary material}

Supplementary data associated with this article can be found, in the online version, at http://dx.doi.org/10.1016/j.ympev.2013.12. 002.

\section{References}

Anthony, M.R.L., Kay, R.F., 1993. Tooth form and diet in ateline and alouattine primates: reflections on the comparative method. Am. J. Sci. 283A, 356382.

Antoine, P.-O., Marivaux, L., Croft, D.A., Billet, G., Ganerød, M., Jaramillo, C., Martin, T., Orliac, M.J., Tejada, J., Altamirano, A.J., Duranthon, F., Fanjat, G., Rousse, S. Gismondi, R.S., 2012. Middle Eocene rodents from Peruvian Amazonia reveal the pattern and timing of caviomorph origins and biogeography. Proc. Roy. Soc. B Biol. Sci. 279, 1319-1326.

Ayres, J.M., Clutton-Brock, T.H., 1992. River boundaries and species range size in Amazonian primates. Am. Nat. 140, 531-537.

Benjamin, M.T., Johnson, N.M., Naeser, C.W., 1987. Recent rapid uplift in the Bolivian Andes: evidence from fission-track dating. Geology 15, 680-683.

Bershaw, J., Garzione, C.N., Higgins, P., MacFadden, B.J., Anaya, F., Alvarenga, H. 2010. Spatial-temporal changes in Andean plateau climate and elevation from stable isotopes of mammal teeth. Earth Planet. Sci. Lett. 289, 530-538.

Blisniuk, P.M., Stern, L.A., Chamberlain, C.P., Idelman, B., Zeitler, P.K., 2005. Climatic and ecologic changes during Miocene surface uplift in the Southern Patagonian Andes. Earth Planet. Sci. Lett. 230, 125-142.

Boubli, J.P., Rylands, A.B., Farias, I.P., Alfaro, M.E., Alfaro, J.L., 2012. Cebus phylogenetic relationships: a preliminary reassessment of the diversity of the untufted capuchin monkeys. Am. J. Primatol. 74, 381-393.

Campbell, K.E. (Ed.), 2004. The Paleogene Mammalian Fauna of Santa Rosa, Amazonian Peru. Natural History Museum of Los Angeles County, Los Angeles, CA.

Cartelle, C., Hartwig, W.C., 1996. A new extinct primate among the Pleistocene megafauna of Bahia, Brazil. Proc. Natl. Acad. Sci. USA 93, 6405-6409.

Chaimanee, Y., Chavasseau, O., Beard, K.C., Kyaw, A.A., Soe, A.N., Sein, C., Lazzaria, V. Marivaux, L., Marandat, B., Swe, M., Rugbumrung, M., Lwin, T., Valentin, X., ZinMaung-Maung-Thein, Jaeger, J.-J., 2012. Late middle Eocene primate from Myanmar and the initial anthropoid colonization of Africa. Proc. Natl. Acad. USA 109, 10293-10297.

Collard, M., Wood, B.A., 2000. How reliable are human phylogenetic hypotheses? Proc. Natl. Acad. USA 97, 5003-5006.

Collins, A.C., Dubach, J.M., 2000. Phylogenetic relationships of spider monkeys Ateles) based on mitochondrial DNA variation. Int. J. Primatol. 21, 381-420.

Colwell, R.K., 2000. A barrier runs through it... or maybe just a river. Proc. Nat. Acad. Sci. 97, 13470-13472.

Cooke, S.B., Rosenberger, A.L., Turvey, S., 2011. An extinct monkey from Haiti and the origins of the Greater Antillean primates. Proc. Nat. Acad. Sci. 108, 26992704

Cortés-Ortiz, L., Bermingham, E., Rico, C., Rodríguez-Luna, E., Sampaio, I., Ruiz García, M., 2003. Molecular systematics and biogeography of the Neotropical monkey genus Alouatta. Mol. Phylogenet. Evol. 26, 64-81.

Cuitiño, J.I., Scasso, R.A., 2013. Reworked pyroclastic beds in the early Miocene of Patagonia: reaction in response to high sediment supply during explosive volcanic events. Sed. Geol. 289, 194-209.

Cunningham, C.W., 1997. Can three incongruence tests predict when data should be combined? Mol. Biol. Evol. 14, 733-740.

Dagosto, M., Gebo, D.L., 1994. Postcranial anatomy and the origin of the Anthropoidea. In: Fleagle, J.G., Kay, R.F. (Eds.), Anthropoid Origins: The Fossil Evidence. Plenum Press, New York, pp. 567-594.

Dávila, F.M., Lithgow-Bertelloni, C., 2013. Dynamic topography of South America. J S. Am. Earth Sci. 43, 127-144.

Dávila, F.M., Lithgow-Bertelloni, C., Giménez, M., 2010. Tectonic and dynamic controls on the topography and subsidence of the Argentine Pampas: the role of the flat slab. Earth Planet. Sci. Lett. 295, 187-194.

Dunn, R.E, Madden, R.H. Kohn, M.J., Schmitz, M.D., Strömberg C.A.E., Carlini, A.A. Ré, G.H., Crowley, J., 2013. A new chronology for middle Eocene-early Miocene South American land mammal ages. Geol. Soc. Am. Bull. 125, 539-555.

Eldredge, N., 1985. Unfinished Synthesis: Biological Hierarchies and Modern Evolutionary Thought. Oxford University Press, New York.

Elton, C.S., 1927. Animal Ecology. MacMillan Co., New York.

Farris, J.S., Kallersjo, M., Kluge, A.G., Bult, C., 1995. Constructing a significance test for incongruence. Syst. Biol. 44, 570-572.

Fleagle, J.G., 1990. New fossil platyrrhines from the Pinturas Formation, southern Argentina. J. Hum. Evol. 19, 61-85.

Fleagle, J.G., Kay, R.F., 1997. Platyrrhines, catarrhines and the fossil record. In: Kinzey, W.G. (Ed.), New World Primates: Ecology, Evolution and Behavior. Aldine, New York, pp. 3-24.

Fleagle, J.G., Rosenberger, A.L., 1983. Cranial morphology of the earliest anthropoids In: Sakka, M. (Ed.), Morphologie Evolution Morphogenese du Crane et Origine de l'Homme. Centre National de Recherche Scientifique, Paris, pp. 141-155.

Fleagle, J.G., Tejedor, M.F., 2002. Early platyrrhines of southern South America. In: Hartwig, W.C. (Ed.), The Primate Fossil Record. Cambridge University Press, Cambridge, pp. 161-173.

Fleagle, J.G., Powers, D.W., Conroy, G.C., Watters, J.P., 1987. New fossil platyrrhines from Santa Cruz Province, Argentina. Folia Primatol. 48, 65-77.

Fleagle, J.G., Perkins, M.E., Heizler, M.T., Nash, B., Bown, T.M., Tauber, A.A., Dozo, M.T., Tejedor, M.F., 2012. Absolute and relative ages of fossil localities in the Santa Cruz and Pinturas Formations. In: Vizcaíno, S.F., Kay, R.F., Bargo, M.S (Eds.), Early Miocene Paleobiology in Patagonia: High-Latitude Paleocommunities of the Santa Cruz Formation. Cambridge University Press, Cambridge, UK, pp. 41-58. 
Flynn, J.J., Wyss, A.R., Charrier, R., Swisher, C.C.I., 1995. An early Miocene anthropoid skull from the Chilean Andes. Nature 373, 603-607.

Flynn, J.J., Guerrero, J., Swisher III, C.C., 1997. Geochronology of the Honda Group. In: Kay, R.F., Madden, R.H., Cifelli, R.L., Flynn, J.J. (Eds.), Vertebrate Paleontology in the Neotropics. Smithsonian Institution Press, Washington, D.C., pp. 44-60.

Ford, S.M., 1980. A Systematic Revision of the Platyrrhini based on Features of the Postcranium. P.D. Dissertation. Anthropology. University of Pittsburgh, Pittsburgh, PA, p. 419.

Ford, S.M., 1986. Systematics of the New World monkeys. In: Swindler, D.R., Erwin, J. (Eds.), Comparative Primate Biology. Vol. I, Systematics, Evolution, and Anatomy. Alan R. Liss, New York, pp. 73-135.

Ford, S.M., 1994. Primitive platyrrhines? Perspectives on anthropoid origins from platyrrhine, parapithecid, and preanthropoid postcrania. In: Fleagle, J.G., Kay, R.F. (Eds.), Anthropoid Origins: The Fossil Evidence. Plenum Press, New York, pp. 595-676.

Ford, S.M., 2006. The biogeographic history of Mesoamerican primates. In: Estrada, A., Garber, P., Pavelka, M.S.M., Luecke, L. (Eds.), New Perspectives in the Study of Mesoamerican Primates. Springer, US, pp. 81-114.

Foster, G.L., Lear, C.H., Rae, J.W.B., 2012. The evolution of pCO2, ice volume and climate during the middle Miocene. Earth Planet. Sci. Lett. 341-344, 243-254.

Garreaud, R.D., Molina, A., Farias, M., 2010. Andean uplift, ocean cooling and Atacama hyperaridity: a climate modeling perspective. Earth Planet. Sci. Lett. 292, 39-50.

Gradstein, F.M., Ogg, J.G., Smith, A., 2004. A Geological Time Scale. Cambridge University Press, Cambridge, UK.

Hartley, A.J., 2003. Andean uplift and climatic change. J. Geol. Soc. Lond. 160, 7-10.

Hartwig, W.C., 1993. Comparative Morphology, Ontogeny and Phylogenetic Analysis of the Platyrrhine Cranium. Ph. D. Dissertation. University of California, Berkeley, Berkeley, CA, p. 628.

Hartwig, W.C., Cartelle, C., 1996. A complete skeleton of the giant South American primate Protopithecus. Nature 381, 307-311.

Hartwig, W.C., Meldrum, D.J., 2002. Miocene platyrrhines of the northern Neotropics. In: Hartwig, W.C. (Ed.), The Primate Fossil Record. Cambridge University Press, Cambridge, pp. 175-188.

Heads, M., 2010. Evolution and biogeography of primates: a new model based on molecular phylogenetics, vicariance and plate tectonics. Zool. Scr. 39, 107-127.

Hedges, S.B., 2006. Paleogeography of the Antilles and origin of West Indian terrestrial vertebrates. Ann. Mo. Bot. Gard. 93, 231-244.

Hernández, R.M., Jordan, T.E., Dalenz Farjat, A., Echavarría, L., Idleman, B.D. Reynolds, J.H., 2005. Age, distribution, tectonics, and eustatic controls of the Paranense and Caribbean marine transgressions in southern Bolivia and Argentina. J. S. Am. Earth Sci. 19, 495-512.

Hershkovitz, P., 1970. Notes on Tertiary platyrrhine monkeys and description of a new genus from the late Miocene of Colombia. Folia Primatol. 12, 1-37.

Hershkovitz, P., 1974. A new genus of late Oligocene monkey (Cebidae, Platyrrhini) with notes on postorbital closure and platyrrhine evolution. Folia Primatol. 21, $1-35$.

Hodgson, J.A., Sterner, K.N., Matthews, L.J., Burrell, A.S., Jani, R.A., Raaum, R.L., Stewart, C.B., Disotell, T.R., 2009. Successive radiations, not stasis, in the South American primate fauna. Proc. Nat. Acad. Sci. USA 106, 5534-5539.

Hoffstetter, R., 1977. Phylogenie des primates. Bull. Mém. Soc. Anthropol. Paris 4 (Série 13), 327-352.

Hoorn, C., Wesselingh, F., 2010. Amazonia, Landscape and Species Evolution: A Look into the Past. Wiley-Blackwell.

Hoorn, C., Guerrero, J., Sarmiento, G.A., Lorente, M.A., 1995. Andean tectonics as a cause for changing drainage patterns in Miocene northern South America. Geology 23, 237-240.

Horovitz, I., 1999. A Phylogenetic Study of Living and Fossil Platyrrhines. American Museum Novitates 3269, New York, NY, pp. 1-40.

Horovitz, I., MacPhee, R.D.E., 1999. The Quaternary Cuban platyrrhine Paralouatta varonai and the origin of Antillean monkeys. J. Hum. Evol. 36, 33-68.

Iturralde-Vinent, M.A., MacPhee, R.D.E., 1999. Paleogeography of the Caribbean region: implications for Cenozoic biogeography. Bull. Am. Mus. Nat. Hist., 1-95.

Jones, A.L., 2008. The evolution of brachiation in ateline primates, ancestral character states and history. Am. J. Phys. Anthropol. 137, 123-144.

Kay, R.F., 1990. The phyletic relationships of extant and fossil Pitheciinae (Platyrrhini, Anthropoidea). J. Hum. Evol. 19, 175-208.

Kay, R.F., 1994. "Giant" tamarin from the Miocene of Colombia. Am. J. Phys. Anthropol. 95, 333-353.

Kay, R.F., 2010. A new primate from the Early Miocene of Gran Barranca, Chubut Province, Argentina: paleoecological implications. In: Madden, R.H., Vucetich, G. Carlini, A.A., Kay, R.F. (Eds.), The Paleontology of Gran Barranca: Evolution and Environmental Change through the Middle Cenozoic of Patagonia. Cambridge University Press, Cambridge, pp. 220-239.

Kay, R.F., 2012. Evidence for an Asian origin of stem anthropoids. Proc. Natl. Acad. USA 109, 10132-10133.

Kay, R.F., Cozzuol, M.A., 2006. New platyrrhine monkeys from the Solimoes Formation (late Miocene, Acre State, Brazil). J. Hum. Evol. 50, 673-686.

Kay, R.F., Fleagle, J.G., 2010. Stem taxa, homoplasy, long lineages and the phylogenetic position of Dolichocebus. J. Hum. Evol. 59, 218-222.

Kay, R.F., Frailey, C.D., 1993. Large fossil platyrrhines from the Río Acre fauna, late Miocene, western Amazonia. J. Hum. Evol. 25, 319-327.

Kay, R.F., Meldrum, D.J., 1997. A new small platyrrhine from the Miocene of Colombia and the phyletic position of Callitrichinae. In: Kay, R.F., Madden, R.H., Cifelli, R.L., Flynn, J.J. (Eds.), Vertebrate Paleontology in the Neotropics. Smithsonian Institution Press, Washington, D.C., pp. 435-458.
Kay, R.F., Williams, B.A., 1994. Cladistics, computers, and character analysis. Evol. Anthropol. 3, 32-35.

Kay, R.F., Madden, R.H., Plavcan, J.M., Cifelli, R.L., Guerrero-Diaz, J., 1987. Stirtonia victoriae, a new species of Miocene Colombian primate. J. Hum. Evol. 16, 173196.

Kay, R.F., Johnson, D.J., Meldrum, D.J., 1998a. A new pitheciin primate from the middle Miocene of Argentina. Am. J. Primatol. 45, 317-336.

Kay, R.F., MacFadden, B.J., Madden, R.H., Sandeman, H., Anaya, F., 1998b. Revised age of the Salla beds, Bolivia, and its bearing on the age of the Deseadan South American Land Mammal 'Age'. J. Vertebr. Paleontol. 18, 189-199.

Kay, R.F., Williams, B.A., Anaya, F., 2002. The adaptations of Branisella boliviana, the earliest South American monkey. In: Plavcan, J.M., van Schaik, C., Kay, R.F., Jungers, W.L. (Eds.), Reconstructing Behavior in the Primate Fossil Record. Kluwer Academic/Plenum Publishers, New York, pp. 339-370.

Kay, R.F., Campbell, V.M., Rossie, J.B., Colbert, M.W., Rowe, T., 2004a. The olfactory fossa of Tremacebus harringtoni (Platyrrhini, early Miocene, Sacanana, Argentina): implications for activity pattern. Anat. Rec. 281A, 1157-1172.

Kay, R.F., Schmitt, D., Vinyard, C., Perry, J.M.G., Takai, M., Shigehara, N., Egi, N., 2004b. The paleobiology of Amphipithecidae, South Asian late Eocene primates. J. Hum. Evol. 46, 3-25.

Kay, R.F., Williams, B.A., Ross, C.F., Takai, M., Shigehara, N., 2004c. Anthropoid origins: a phylogenetic analysis. In: Ross, C.F., Kay, R.F. (Eds.), Anthropoid Origins: New Visions. Kluwer/Plenum, New York, pp. 91-135.

Kay, R.F., Fleagle, J.G., Mitchell, T.R.T., Colbert, M.W., Bown, T.M., Powers, D.W., 2008a. The anatomy of Dolichocebus gaimanensis, a primitive platyrrhine monkey from Argentina. J. Hum. Evol. 54, 323-382.

Kay, R.F., Ross, J., Simons, E.L., 2008b. The basicranial anatomy of African Eocene/ Oligocene anthropoids. Are there any clues for platyrrhine origins? In: Fleagle, J.G., Gilbert, C.G. (Eds.), Elwyn L. Simons: A Search for Origins. Springer, New York, pp. 125-158.

Kay, R.F., Hunt, K.D., Beeker, C.D., Conrad, G.W., Johnson, C.C., Keller, J., 2011. Preliminary notes on a newly discovered skull of the extinct Hispaniolian monkey Antillothrix from Hispaniola and the origin of the Greater Antillean monkeys. J. Hum. Evol. 60, 124-128.

Kay, R.F., Perry, J.M.G., Malinzak, M.D., Allen, K.L., Kirk, E.C., Plavcan, J.M., Fleagle, J.G., 2012a. The paleobiology of Santacrucian primates. In: Vizcaíno, S., Kay, R.F., Bargo, M. (Eds.), Early Miocene Paleobiology in Patagonia: High-Latitude Paleocommunities of the Santa Cruz Formation. Cambridge University Press, Cambridge, UK, pp. 306-330.

Kay, R.F., Vizcaíno, S.F., Bargo, M.S., 2012b. A review of the paleoenvironment and paleoecology of the Miocene Santa Cruz Formation. In: Vizcaíno, S.F., Kay, R.F., Bargo, M.S. (Eds.), Early Miocene Paleobiology in Patagonia: High-Latitude Paleocommunities of the Santa Cruz Formation. Cambridge University Press, Cambridge, UK, pp. 331-364.

Kay, R.F., Meldrum, D.J., Takai, M., 2013. Pitheciidae and other platyrrhine seed predators. In: Veiga, L., Barnett, A., Ferrari, S., Norconk, M. (Eds.), Evolutionary Biology and Conservation of Titis, Sakis and Uacaris. Cambridge University Press, Cambridge, UK, pp. 3-12.

Kirby, M.X., Jones, D.S., MacFadden, B.J., 2008. Lower Miocene stratigraphy along the Panama Canal and its bearing on the Central American Peninsula. PLoS ONE 3, e2791.

Koepfli, K.-P., Gompper, M.E., Eizirik, E., Ho, C.-C., Linden, L., Maldonado, J.E., Wayne, R.K., 2007. Phylogeny of the Procyonidae (Mammalia: Carnivora): molecules, morphology and the Great American Interchange. Mol. Phylogenet. Evol. 43, $1076-1095$.

Lavergne, A., Ruiz-García, M., Catzeflis, F., Lacote, S., Contamin, H., MercereauPuijalon, O., Lacoste, V., de Thoisy, B., 2010. Phylogeny and phylogeography of squirrel monkeys (genus Saimiri) based on cytochrome b genetic analysis. Am. J. Primatol. 72, 242-253.

Luchterhand, K., Kay, R.F., Madden, R.H., 1986. Mohanamico hershkovitzi, gen et sp. nov., un primate du Miocène moyen d'Amérique du Sud. CR Acad. Sci. II 303, 1753-1758.

Lundberg, J.G., Machado-Allison, A., Kay, R.F., 1986. Miocene characid fishes from Colombia: evolutionary stasis and extirpation. Science 234, 208-209.

Lundberg, J.G., Marshall, L.G., Guerrero, J., Horton, B., Malabarba, M.C.S.L., Wesselingh, F.P., 1998. The stage for Neotropical fish diversification: a history of tropical South American rivers. In: Malabarba, L.R., Reis, R.E., Vari, R.P., Lucena, Z.M., Lucena, C.A.S. (Eds.), Phylogeny and Classification of Neotropical Fishes. Edipucrs, Porto Alegre, Brazil.

Mac Fadden, B.J., 2006. North American Miocene land mammals from Panama. J. Vertebr. Paleontol. 26, 720-734.

MacFadden, B.J., Campbell, K.E., Cifelli, R.L., Siles, O., Johnson, N.M., Naeser, C.W., Zeitler, P.K., 1985. Magnetic polarity stratigraphy and mammalian fauna of the Deseadan (late Oligocene-early Miocene) Salla beds of northern Bolivia. J. Geol. 93, 223-250.

MacPhee, R.D.E., 2005. "First" appearances in the Cenozoic land mammal record of the Greater Antilles: significance and comparison with South American and Antarctic records. J. Biogeogr. 32, 551-564.

MacPhee, R.D.E., 2009. Insulae infortunate: establishing a chronology for late Quaternary mammal extinctions in the West Indies. In: Haynes, G. (Ed.), American Megafaunal Extinctions at the End of the Pleistocene. Springer Science, pp. 169-193.

MacPhee, R.D.E., Horovitz, I., 2004. New craniodental remains of the Quaternary Jamaican monkey Xenothrix mcgregori (Xenotrichini, Callicebinae, Pitheciidae), with a reconsideration of the Aotus hypothesis. American Museum Novitates 3434, New York, NY, pp. 1-51. 
MacPhee, R.D.E., Iturralde-Vinent, M.A., 1995. Earliest monkey from greater Antilles. J. Hum. Evol. 28, 197-200.

MacPhee, R.D.E., Meldrum, D.J., 2006. Postcranial remains of the Extinct monkeys of the greater Antilles, with evidence for semiterrestriality in Paralouatta. American Museum Novitates 3516, pp. 1-37.

MacPhee, R.D.E., Iturralde-Vinent, M.A., Gaffney, E.S., 2003. Domo de Zaza, an Early Miocene Vertebrate Locality in South-Central Cuba, with Notes on the Tectonic Evolution of Puerto Rico and the Mona Passage. American Museum Novitates, pp. $1-42$.

Madden, R.H., Guerrero, J., Kay, R.F., Flynn, J.J., Swisher III, C.C., Walton, A.H., 1997. The Laventan stage and Laventan age: new chronostratigraphic and geochronologic units for the Miocene of South America. In: Kay, R.F., Madden, R.H., Cifelli, R.L., Flynn, J.J. (Eds.), Vertebrate Paleontology in the Neotropics. Smithsonian Institution Press, Washington, D.C., pp. 499-519.

Malumián, N., 1999. La sedimentación y el volcanismo Terciarios en La Patagonia extraandina. In: Caminos, R. (Ed.), Geología Argentina. Instituto de Geología y Recursos Minerales, Buenos Aires, pp. 557-612.

Marivaux, L., 2006. The eosimiid and amphipithecid primates (Anthropoidea) from the Oligocene of the Bugti Hills (Balochistan, Pakistan): new insight into early higher primate evolution in South Asia. Palaeovertebrata, Montpellier 34, 29109.

Marivaux, L., Salas-Gismondi, R., Tejada, J., Billet, G., Louterbach, M.l., Vink, J., Bailleul, J., Roddaz, M., Antoine, P.-O., 2012. A platyrrhine talus from the early Miocene of Peru (Amazonian Madre de Dios Sub-Andean zone). J. Hum. Evol. 63, 696-703.

Marshall, L.G., 1988. Land mammals and the Great American interchange. Am. Sci. 76, 380-388.

Matthew, W.D., 1919. Recent discoveries of fossil vertebrates in the West Indies and their bearing on the origin of the Antillean Fauna. Proc. Am. Philos. Soc. 58, $161-$ 181.

Meldrum, D.J., Kay, R.F., 1997. Nuciruptor rubricae, a new pitheciin seed predator from the Miocene of Colombia. Am. J. Phys. Anthropol. 102, 407-427.

Meldrum, D.J., Lemelin, P., 1991. Axial skeleton of Cebupithecia sarmientoi (Pitheciinae, Platyrrhini) from the middle Miocene of La Venta, Colombia. Am. J. Primatol. 25, 69-90.

Miller, K.G., Kominz, M.A., Browning, J.V., Wright, J.D., Mountain, G.S., Katz, M.E., Sugarman, P.J., Cramer, B.S., Christie-Blick, N., Pekar, S.F., 2005. The Phanerozoic record of global sea-level change. Science 310, 1293-1298.

Morales Jimenez, A., this volume-a. Biogeography of spider monkeys. Mol. Phylogenet. Evol.

Morales Jimenez, A., this volume-b. Phylogeography of Mesoamerican spider monkeys. Mol. Phylogenet. Evol.

Negri, F.R., Bocquentin-Villanueva, J., Frerigolo, J., Antoine, P.-O., 2010. A review of Tertiary mammal faunas and birds from western Amazonia. In: Hoorn, C., Wesselingh, F.P. (Eds.), Amazonia: Landscape and Species Evolution: A Look into the Past. Blackwell Publishing, pp. 245-258.

Opazo, J.C., Wildman, D.E., Prychitko, T., Johnson, R.M., Goodman, M., 2006. Phylogenetic relationships and divergence times among New World monkeys (Platyrrhini, Primates). Mol. Phylogenet. Evol. 40, 274-280.

Osterholz, M., Walter, L., Roos, C., 2009. Retropositional events consolidate the branching order among New World monkey genera. Mol. Phylogenet. Evol. 50, 507-513.

Parham, J.F., Donoghue, P.C.J., Bell, C.J., Calway, T.D., Head, J.J., Holroyd, P.A., Inoue, J.G., Irmis, R.B., Joyce, W.G., Ksepka, D.T., Patané, J.S.L., Smith, N.D., Tarver, J.E., van Tuinen, M., Yang, Z., Angielczyk, K.D., Greenwood, J.M., Hipsley, C.A., Jacobs, L., Makovicky, P.J., Müller, J., Smith, K.T., Theodor, J.M., Warnock, R.C.M., Benton, M.J., 2012. Best practices for justifying fossil calibrations. Syst. Biol. 61, 346359.

Pascual, R., Ortiz Jaureguizar, E., 1990. Evolving climates and mammal faunas in Cenozoic South America. J. Hum. Evol. 19, 23-60.

Perelman, P., Johnson, W.E., Roos, C., Seuánez, H.N., Horvath, J.E., Moreira, M.A.M., Kessing, B., Pontius, J., Roelke, M., Rumpler, Y., Schneider, M.P.C., Silva, A., O’Brien, S.J., Pecon-Slattery, J., 2011. A molecular phylogeny of living primates. PLoS Genet. 3, e1001342.

Perez, S.I., Tejedor, M.F., Novo, N.M., Aristide, L., 2013. Divergence times and the evolutionary radiation of New World monkeys (Platyrrhini, Primates): an analysis of fossil and molecular data. PLoS ONE 8, e68029.

Perkins, M.E., Fleagle, J.G., Heizler, M.T., Nash, B., Bown, T.M., Tauber, A.A., Dozo, M.T., 2012. Tephrochronology of the Miocene Santa Cruz and Pinturas Formations, Argentina. In: Vizcaíno, S.F., Kay, R.F., Bargo, M.S. (Eds.), Early Miocene Paleobiology in Patagonia: High-Latitude Paleocommunities of the Santa Cruz Formation. Cambridge University Press, Cambridge, UK, pp. 23-40.

Perry, J.G.M., Kay, R.F., Vizcaíno, S., Bargo, M., in press. Oldest known cranium of a juvenile New World monkey (Early Miocene, Patagonia, Argentina): implications for the taxonomy, and the molar eruption pattern of early platyrrhines. J. Hum. Evol.

Pindell, J., Kennan, L., 2009. Tectonic evolution of the Gulf of Mexico, Caribbean and northern South America in the mantle reference frame: an update. In: James, K. Lorente, M.A., Pindell, J. (Eds.), The Geology and Evolution of the Region between North and South America. Geological Society of London, London.

Pindell, J.L., Cande, S.C., Pitman III, W.C., Rowley, D.B., Dewey, J.F., Labrecque, J., Haxby, W., 1988. A plate-kinematic framework for models of Caribbean evolution. Tectonophysics $155,121-138$

Ray, D.A., Xing, J., Hedges, D.J., Hall, M.A., Laborde, M.E., Anders, B.A., White, B.R., Stoilova, N., Fowlkes, J.D., Landry, K.E., Chemnik, L.G., Ryder, O.A., Batzer, M.A.,
2005. Alu insertion loci and platyrrhine primate phylogeny. Mol. Phylogenet. Evol. 35, 117-126.

Ré, G.H., Bellosi, E.S., Heizler, M., Vilas, J.F., Madden, R.H., Carlini, A.A., Kay, R.F. Vucetich, M.G., 2010. A geochronology for the Sarmiento Formation at Gran Barranca. In: Madden, R.H., Vucetich, G., Carlini, A.A., Kay, R.F. (Eds.), The Paleontology of Gran Barranca: Evolution and Environmental Change through the Middle Cenozoic of Patagonia. Cambridge University Press, Cambridge, pp. 46-60.

Reguero, M.A., Dozo, M.T., Cerdeño, E., 2007. A poorly known rodentlike mammal (Pachyrukhinae, Hegetotheriidae, Notoungulata) from the Deseadan (late Oligocene) of Argentina. Paleoecology, biogeography, and radiation of the rodentlike ungulates in South America. J. Paleontol. 81, 1301-1307.

Rosenberger, A.L., 1977. Xenothrix and ceboid phylogeny. J. Hum. Evol. 6, 461-481.

Rosenberger, A.L., 1979. Cranial anatomy and implications of Dolichocebus, a late Oligocene ceboid primate. Science 279, 416-418.

Rosenberger, A.L., 1982. Supposed squirrel monkey affinities of the late Oligocene Dolichocebus gaimanensis, reply to P. Hershkovitz. Nature 298, 202.

Rosenberger, A.L., 2000. Pitheciinae. In: Delson, E., Tattersal, I., Van Couvering, J. (Eds.), Encyclopedia of Human Evolution and Prehistory, second ed. Garland Publishing Co., New York, pp. 562-563.

Rosenberger, A.L., 2002. Platyrrhine paleontology and systematics: the paradigm shifts. In: Hartwig, W.C. (Ed.), The Primate Fossil Record. Cambridge University Press, Cambridge, pp. 151-159.

Rosenberger, A.L., 2010. Platyrrhines, PAUP, parallelism, and the long lineage hypothesis: a reply to Kay et al. (2008). J. Hum. Evol. 59, 214-217.

Rosenberger, A.L., 2011. Evolutionary morphology, platyrrhine evolution, and systematics. The Anatomical Record 294, 1955-1974.

Rosenberger, A.L., Tejedor, M.F., 2013. The misbegotten: long lineages, long branches and the interrelationships of Aotus, Callicebus and the Saki-Uacaris. In: Veiga, L.M., Barnett, A.A., Ferrari, S.F., Norconk, M.A. (Eds.), Evolutionary Biology and Conservation of Titis, Sakis and Uacaris. Cambridge University Press, Cambridge, UK.

Rosenberger, A.L., Setoguchi, T., Shigehara, N., 1990a. The fossil record of callitrichine primates. J. Hum. Evol. 19, 209-236.

Rosenberger, A.L., Setoguchi, T., Shigehara, N., 1990b. Towards a paleontology of the New World callitrichine primates. J. Hum. Evol. 19, 209-236.

Rosenberger, A.L., Hartwig, W.C., Takai, M., Setoguchi, T., Shigehara, N., 1991a. Dental variability in Saimiri and the taxonomic status of Neosaimiri fieldsi, an early squirrel monkey from La Venta, Colombia. Int. J. Primatol. 12, 291-302.

Rosenberger, A.L., Hartwig, W.C., Wolff, R.C., 1991b. Szalatavus attricuspis, an early platyrrhine primate. Folia Primatol. 56, 225-233.

Rosenberger, A.L., Setoguchi, T., Hartwig, W.C., 1991c. Laventiana annectens, new genus and species: fossil evidence for the origins of callitrichine New World monkeys. Proc. Natl. Acad. USA 88, 2137-2140.

Rosenberger, A.L., Cooke, S.B., Rímoli, R., Ni, X., Cardoso, L., 2011. First skull of Antillothrix bernensis, an extinct relict monkey from the Dominican Republic Proc. Roy. Soc. B Biol. Sci. 278, 67-74.

Schrago, C.G., 2007. On the time scale of New World primate diversification. Am. J Phys. Anthropol. 132, 344-354.

Seiffert, E.R., 2006. Revised age estimates for the later Paleogene mammal faunas of Egypt and Oman. Proc. Nat. Acad. Sci. USA 103, 5000-5005.

Seiffert, E.R., Simons, E.L., Clyde, W.C., Rossie, J.B., Attia, Y., Bown, T.M., Chatrath, P., Mathison, M.E., 2005. Basal anthropoids from Egypt and the antiquity of Africa's higher primate radiation. Science 310, 300-304.

Seiffert, E.R., Perry, J.G.M., Simons, E.L., Boyer, D.M., 2009. Convergent evolution of anthropoid-like adaptations in Eocene adapiform primates. Nature 461, 1118 1121.

Setoguchi, T., Rosenberger, A.L., 1985. Miocene marmosets: first fossil evidence. Int. J. Primatol. 6, 615-625.

Setoguchi, T., Rosenberger, A.L., 1987. A fossil owl monkey from La Venta, Colombia. Nature 326, 692-694.

Setoguchi, T., Takai, M., Shigehara, N., 1990. A new ceboid monkey, closely related to Neosaimiri, found in the Upper Red Bed in the La Venta badlands, middle Miocene of Colombia, South America. Kyoto University Overseas Research Reports of New World Monkeys 7, 9-13.

Slowinski, J.B., 1993. "Unordered” versus “ordered” characters. Syst. Biol. 42, 155 165.

Springer, M., Teeling, E., Madsen, O., Stanhope, M., de Jong, W.W., 2001. Integrated fossil and molecular data reconstruct bat ecolocation. Proc. Natl. Acad. Sci. USA 98, 6241-6246.

Springer, M.S., Meredith, R.W., Gatesy, J., Emerling, C.A., Park, J., Rabosky, D.L., Stadler, T., Steiner, C., Ryder, O.A., Janečka, J.E., Fisher, C.A., Murphy, W.J., 2012. Macroevolutionary dynamics and historical biogeography of primate diversification inferred from a species supermatrix. PLOS ONE 7, e49521.

Steadman, D.W., Martin, P.S., MacPhee, R.D.E., Jull, A.J.T., McDonald, H.G., Woods, C.A., Iturralde-Vinent, M., Hodgins, G.W.L., 2005. Asynchronous extinction of late Quaternary sloths on continents and islands. Proc. Nat. Acad. Sci. USA 102, $11763-11768$.

Stirton, R.A., 1951. Ceboid Monkeys from the Miocene of Colombia, vol. 20 University of California Publications in Geological Sciences, pp. 315-356.

Strait, D.S., Grine, F.E., 2004. Inferring hominoid and early hominid phylogeny using craniodental characters: the role of fossil taxa. J. Hum. Evol. 47, 399-452.

Strecker, M., Alonso, R., Bookhagen, B., Carrapa, B., Hilley, G., Sobel, E., Trauth, M. 2007. Tectonics and climate of the southern central Andes. Annu. Rev. Earth Planet. Sci. 35, 747-787. 
ARTICLE IN PRESS

R.F. Kay/Molecular Phylogenetics and Evolution $x x x$ (2014) $x x x-x x x$

17

Swofford, D.L., 2002. PAUP. Phylogenetic Analysis using Parsimony ( ${ }^{*}$ and other methods). Version 4. Sinauer Associates, Sunderland, MA, USA.

Takai, M., 1994. New specimens of Neosaimiri fieldsi, a middle Miocene ancestor of the squirrel monkeys from La Venta, Colombia. J. Hum. Evol. 27, 329-360.

Takai, M., Anaya, F., 1996. New specimens of the oldest fossil platyrrhine, Branisella boliviana from Salla, Bolivia. Am. J. Phys. Anthropol. 99, 301-318.

Takai, M., Anaya, F., Shigehara, N., Setoguchi, T., 2000. New fossil materials of the earliest New World monkey, Branisella boliviana, and the problem of platyrrhine origins. Am. J. Phys. Anthropol. 111, 263-281.

Takai, M., Anaya, F., Suzuki, H., Shigehara, N., Setoguchi, T., 2001. A new platyrrhine from the middle Miocene of La Venta, Colombia, and the phyletic position of Callicebinae. Anthropol. Sci. (Jpn.) 109, 289-307.

Tejedor, M.F., 2013. Sistemática, evolución y paleobiogeografía de los primates Platyrrhini. Revista Mus. La Plata, Secc. Zool. 20, 20-39.

Tejedor, M.F., Rosenberger, A.L., 2008. A Neotype for Homunculus patagonicus Amegnino, 1891, and a new interpretation of the taxon. PaleoAnthropology 2008, 67-82.

Tejedor, M.F., Tauber, A.A., Rosenberger, A.L., Swisher III, C.C., Palacios, M.E., 2006. New primate genus from the Miocene of Argentina. Proc. Natl. Acad. USA 103, 5437-5441.

Veiga, E.C., 2009. Tafoflora paleógena da formação Tremembé, ocorrência em afloramento do Km 11 da Rodovia SP-123, município de Taubaté, Bacia sedimentar de Taubaté, Brasil. Centro de Pós-Graduaçåo e Pesquisa. Universidade Guarulhos, Guarulhos, São Paulo State, Brazil, p. 177.
Wadge, G., Burke, K., 1993. Neogene Caribbean plate rotation and associated Central American tectonic evolution. Tectonics 2, 633-643.

Wallace, A.R., 1852. On the monkeys of the Amazon. Proc. Zool. Soc. Lond. 20, 107110.

Wesselingh, F.P., Hoorn, C., Kroonenberg, S.B., Antonelli, A., Lundberg, J.G., Vonhoff, H.B., Hoogheimstra, H., 2010. On the origin of Amazonian landscapes and biodiversity: a synthesis. In: Hoorn, C., Wesselingh, F.P. (Eds.), Amazonia, Landscape and Species Evolution: A Look into the Past. Wiley-Blackwell, pp. 421-431.

Wildman, D.E., Jameson, N.M., Opazo, J.C., Yi, S.V., 2009. A fully resolved genus level phylogeny of neotropical primates (Platyrrhini). Mol. Phylogenet. Evol. 53, 694702.

Williams, B.A., 2007. Comparing levels of homoplasy in the primate skeleton. J. Hum. Evol. 52, 480-489.

Williams, B.A., Kay, R.F., Kirk, E.C., 2010. New perspectives on anthropoid origins. Proc. Natl. Acad. USA 107, 4797-4804.

Woodburn, M.O., 2010. The Great American biotic interchange: dispersals, tectonics, climate, sea level and holding pens. J. Mamm. Evol. 17, 245-264.

Zachos, J., Pagani, M., Sloan, L., Thomas, E., Billups, K., 2001. Trends, rhythms, and aberrations in global climate 65 Ma to present. Science 292, 686-693.

Zingeser, M.R., 1973. Dentition of Brachyteles arachnoides with reference to alouattine and ateline affinities. Folia Primatol. 20, 351-390.

Please cite this article in press as: Kay, R.F. Biogeography in deep time - What do phylogenetics, geology, and paleoclimate tell us about early platyrrhine

evolution? Mol. Phylogenet. Evol. (2014), http://dx.doi.org/10.1016/j.ympev.2013.12.002 